\title{
Design, Microwave-Assisted Synthesis and In Silico Prediction Study of Novel Isoxazole Linked Pyranopyrimidinone Conjugates as New Targets for Searching Potential Anti-SARS-CoV-2 Agents
}

\author{
Faisal K. Algethami ${ }^{1, *(\mathbb{D}) \text {, Maher Cherif }}{ }^{2}$, Salma Jlizi ${ }^{2}$, Naoufel Ben Hamadi ${ }^{1,2}$, Anis Romdhane ${ }^{2}$, \\ Mohamed R. Elamin ${ }^{1}$, Mashael A. Alghamdi ${ }^{1}$ and Hichem Ben Jannet ${ }^{2, *}$ D \\ 1 Department of Chemistry, College of Science, Imam Mohammad Ibn Saud Islamic University (IMSIU), \\ Riyadh 11432, Saudi Arabia; bh_naoufel@yahoo.fr (N.B.H.); mohamedrahmt99@gmail.com (M.R.E.); \\ mabalghamdi@imamu.edu.sa (M.A.A.) \\ 2 Laboratory of Heterocyclic Chemistry, Natural Products and Reactivity (LR11ES39), Medicinal Chemistry and \\ Natural Products Team, Faculty of Science of Monastir, University of Monastir, Avenue of Environment, \\ Monastir 5019, Tunisia; cherifmhr13@gmail.com (M.C.); salma.jlizi@gmail.com (S.J.); \\ anis_romdhane@yahoo.fr (A.R.) \\ * Correspondence: falgethami@imamu.edu.sa (F.K.A.); hichem.bjannet@gmail.com (H.B.J.)
}

check for updates

Citation: Algethami, F.K.; Cherif, M.; Jlizi, S.; Ben Hamadi, N.; Romdhane, A.; Elamin, M.R.; Alghamdi, M.A.; Ben Jannet, H. Design,

Microwave-Assisted Synthesis and In Silico Prediction Study of Novel

Isoxazole Linked

Pyranopyrimidinone Conjugates as New Targets for Searching Potential Anti-SARS-CoV-2 Agents. Molecules 2021, 26, 6103. https://doi.org/ $10.3390 /$ molecules 26206103

Academic Editor: Rita Guedes

Received: 6 September 2021

Accepted: 6 October 2021

Published: 10 October 2021

Publisher's Note: MDPI stays neutral with regard to jurisdictional claims in published maps and institutional affiliations.

Copyright: () 2021 by the authors. Licensee MDPI, Basel, Switzerland. This article is an open access article distributed under the terms and conditions of the Creative Commons Attribution (CC BY) license (https:// creativecommons.org/licenses/by/ $4.0 /)$.
Abstract: A series of novel naphthopyrano[2,3-d]pyrimidin-11(12H)-one containing isoxazole nucleus 4 was synthesized under microwave irradiation and classical conditions in moderate to excellent yields upon 1,3-dipolar cycloaddition reaction using various arylnitrile oxides under copper(I) catalyst. A one-pot, three-component reaction, $N$-propargylation and Dimroth rearrangement were used as the key steps for the preparation of the dipolarophiles3. The structures of the synthesized compounds were established by ${ }^{1} \mathrm{H}$ NMR, ${ }^{13} \mathrm{C}$ NMR and HRMS-ES means. The present study aims to also predict the theoretical assembly of the COVID-19 protease (SARS-CoV-2 Mpro) and to discover in advance whether this protein can be targeted by the compounds $\mathbf{4 a - 1}$ and thus be synthesized. The docking scores of these compounds were compared to those of the co-crystallized native ligand inhibitor (N3) which was used as a reference standard. The results showed that all the synthesized compounds (4a-1) gave interesting binding scores compared to those of N3 inhibitor. It was found that compounds $4 \mathbf{a}, 4 \mathbf{e}$ and $4 \mathbf{i}$ achieved greatly similar binding scores and modes of interaction than $\mathrm{N} 3$, indicating promising affinity towards SARS-CoV-2 $\mathrm{M}^{\mathrm{pro}}$. On the other hand, the derivatives $4 \mathbf{k}$, $4 \mathbf{h}$ and $4 \mathbf{j}$ showed binding energy scores $(-8.9,-8.5$ and $-8.4 \mathrm{kcal} / \mathrm{mol}$, respectively) higher than the $\mathrm{M}^{\text {pro }} \mathrm{N} 3$ inhibitor $(-7.0 \mathrm{kcal} / \mathrm{mol})$, revealing, in their turn, a strong interaction with the target protease, although their interactions were not entirely comparable to that of the reference N3.

Keywords: pyranopyrimidinone; isoxazole; copper catalyst; click chemistry; microwave irradiation; in silicomolecular docking; SARS-CoV-2 Mpro inhibitors

\section{Introduction}

Coronaviruses (CoVs) tend to have a high zoonotic potential and according to the World Health Organization (WHO), these viral diseases have emerged as a serious health issue to the world [1]. Consequently, the WHO declared a state of global health emergency to coordinate scientific and medical efforts to rapidly develop a cure for patients [2]. The discovery of an antiviral drug is of immense importance in the current spread of the rapidly modifiable SARS-CoV-2. The aim of the present study was to develop an antiviral drug against the novel COVID-19 virus [3]. One of the ways that several research teams are thinking is to highlight promising molecules and drug compounds by making a virtual screening via molecular docking of drugs approved by the FDA, certain natural substances, and synthetic heterocyclic compounds such as pyranopyrimidinones linked 
to isoxazoles for probable therapeutic outcome. In this context, antiviral compounds have seriously attracted the attention of organic medicinal chemists, who have thought of chemically modifying them in different ways in order to achieve much more active structural analogues.

Naphthalenes have, for a long time, attracted the attention of organic chemists and biologists due to their wide spectrum of biological properties, such as antimicrobial, cytotoxic [4], cardiovascular [5], anti-inflammatory [6], and antiviral (Figure 1, 1-A [7], 1-B [8]).

On the other hand, heterocyclic scaffolds play a central role in drug discovery and development, thus constituting the key structural component of a majority of biologically active moieties. Conjugated pyranes are heterocyclic compounds arousing great interest due to their multiple biological activities, such as antimicrobial [9], anti-tumor [10], influenza inhibition [11] and antiviral (Figure 1, 1-C, 1-D) [12].<smiles>Cc1ccc(N)cc1C(=O)N[C@@H](C)c1cccc2ccccc12</smiles>

GRL-0617<smiles>C[C@H](I)N1CCC(C(=O)Nc2ccc3c(c2)OCO3)CC1</smiles>

GRL-0667

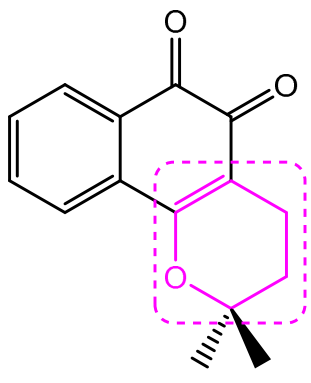

1-C

$\beta$-Lapachone

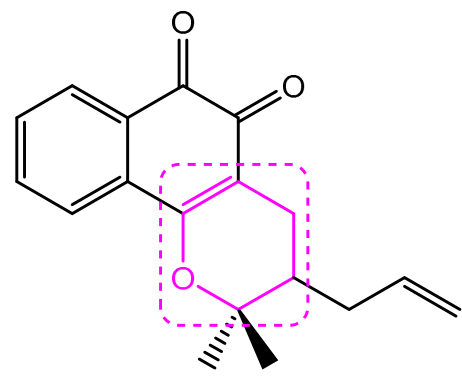

1-D

\section{3-Allyl- $\beta$-lapachone}

Figure 1. Previously reported antiviral naphthalene and conjugated pyran derivatives.

On the other hand, pyrimidines are among the most important nitrogenous heterocyclic classes in medicinal chemistry due to their various extensive biological and therapeutic activities [13]. In this context, the condensed derivatives of pyrimidines are very attractive targets because of their various pharmacological effects, such as anti-tubercular [14], antitumor [15], antityrosinase [16], antiproliferative [17], anti-inflammatory [18] and antiviral (Figure 2, 2-A [19], 2-B [20]).

Furthermore, isoxazole derivatives possess various biological activities such as antiinflammatory [21], antileishmanial [22], trypanocidal [23], antimicrobial [24,25] and antiviral (Figure 2, 2-C [26], 2-D [27]). 


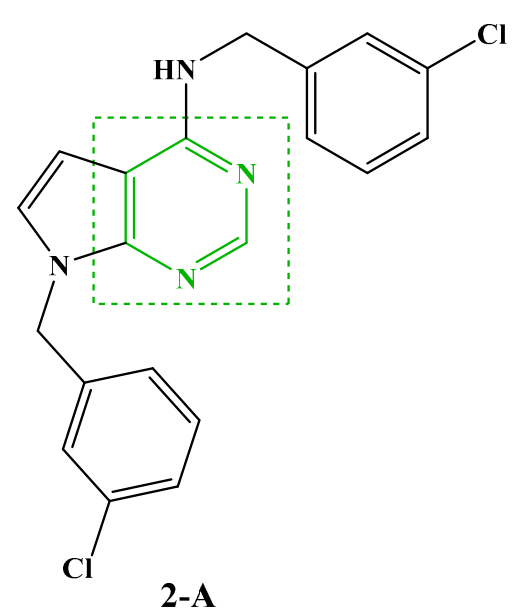

2-A pyrrolo $[2,3-d]$ pyrimidin-4-amine<smiles>CCCOC1=NC(N)=N[C@@H](N)C1C#N</smiles>

2-B

2,4-Diamino-5-cyano-6-

[2-(diisopropoxyphosphorylmethoxy) ethoxy]pyrimidine

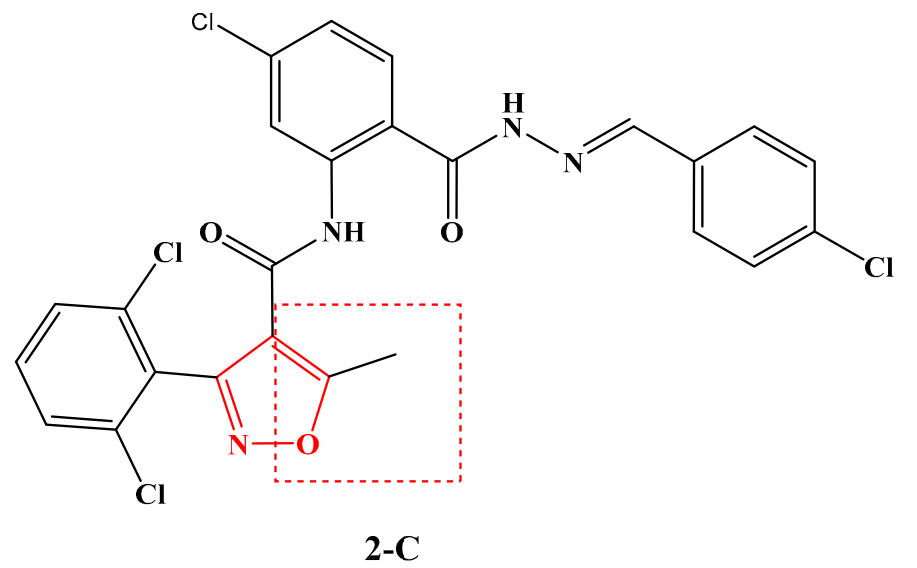

(E)-N-(5-chloro-2-(2-(4-chlorobenzylidene)hydrazine-1-carbonyl) phenyl)-3-(2,6-dichlorophenyl)-5- methylisoxazole-4-carboxamide

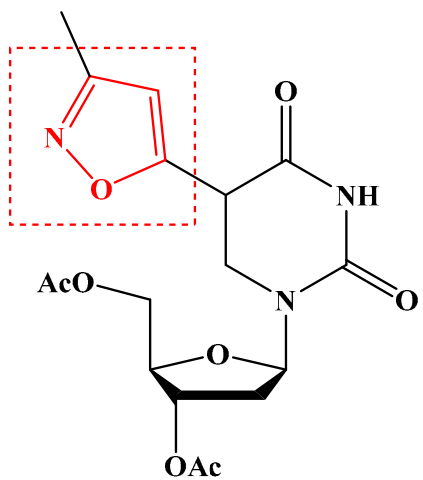

2-D

5-isoxazol-5-yl-2'-deoxyuridine

Figure 2. Previously reported antiviral compounds bearing pyrimidine and isoxazole rings.

In addition, numerous target-based virtual screenings were performed to discover promising protease inhibitors against SARS-CoV-2. In this context, a recent study showed that high throughput virtual screening of more than 10,000 molecules, based on the SARSCoV-2 Mpro structure, resulted in the identification of six small inhibitors molecules [28], one of which is a pyrimidine derivative (Figure 3, 3-A [28]) and the other contains the isoxazole nucleus (Figure 3, 3-B [28]).

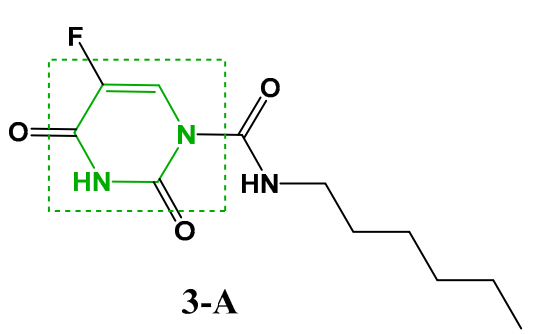

Tideglusib<smiles>Cc1cc(C(=O)N[C@@H](C)C(=O)N[C@@H](C(=O)N[C@@H](CC(C)C)C(=O)N[C@@H](/C=C/C(=O)OCc2ccccc2)C[C@@H]2CCNC2=O)C(C)C)on1</smiles>

Michael acceptor (peptidyl) inhibitor, N3

Figure 3. Structure of SARS-CoV-2 Mpro inhibitors. 
Furthermore, recent work has shown that certain compounds, containing in their structures the pyrimidine (Figure 4, 4-A [29]) and isoxazole (Figure 4, 4-B [30]) units, have shown an anti-SARS-CoV-2 activity.

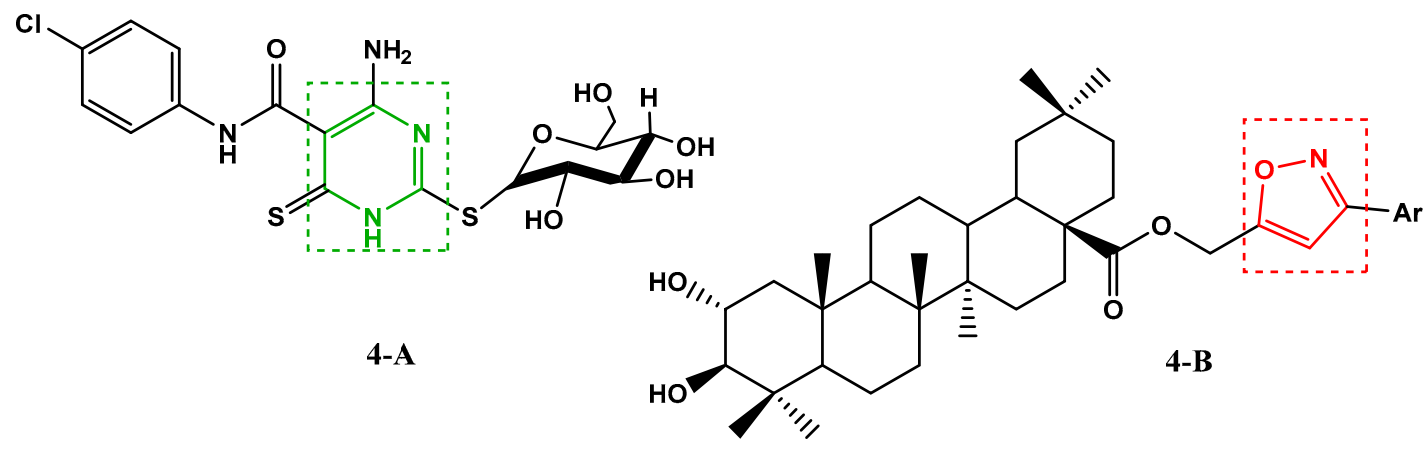

\section{4-A : 4-Amino-N-(4-chlorophenyl)-2-( $\beta$-D-glucopyranosylthio)-6-thioxo- 1,6-dihydropyrimidine-5-carboxamide}

4-B : (3-(4-chlorophenyl) isoxazol-5-yl) methyl-(2 $\alpha, 3 \beta)-2,3-d i h y d r o x y o l e a n-12-e n-28-o a t e$

Figure 4. Previously reported anti-SARS-CoV-2 molecules.

In addition, the junction of the pyrimidine ring with different heterocyclic fragments in the same molecule could lead to a new category of hybrid molecules with pronounced biological power. In this context, and in the continuity of looking for new bioactive pyrimidine compounds [31-33], we report herein the synthesis of a new series of hybrid compounds 4, in three steps (Scheme 1), under conventional heating conditions and by microwave irradiation. We have chosen to integrate into the same molecule the naphthalene, pyran, pyrimidine and isoxazole fragments assigned as antiviral and anti-SARS-CoV-2 agents, as indicated above, with the aim to perform their virtual screening, using molecular docking studies, hoping to find out promising protease inhibitors against COVID-19.<smiles>N#CC1=C(N)Oc2ccc3ccccc3c2C1[Al]</smiles>

Naphtopyranes 1a-c $\mathrm{Ar}=\mathrm{Ph}(\mathbf{a})$, 4-Me-Ph(b), 4-Cl-Ph(c)<smiles>C#CCn1c(C)nc2c(c1=O)C([Al])c1c(ccc3ccccc13)O2</smiles>

$N$-propargylated naphtopyranopyrimidinones 3a-c<smiles>Cc1nc2c(c(=O)n1Cc1cc(C(F)(F)F)no1)C([Al])c1c(ccc3ccccc13)O2</smiles>

Nitrile oxydes

1,3-dipolair cycloaddition

Target hybrid compounds

4a-l

$\mathbf{a}\left(\mathrm{Ar}=\mathrm{Ar}_{1}=\mathrm{Ph}\right), \mathbf{b}\left(\mathrm{Ar}=\mathrm{Ph}, \mathrm{Ar}_{1}=4-\mathrm{Me}-\mathrm{Ph}\right), \mathbf{c}\left(\mathrm{Ar}=\mathrm{Ph}, \mathrm{Ar}_{1}=4-\mathrm{OMe}-\mathrm{Ph}\right), \mathbf{d}\left(\mathrm{Ar}=\mathrm{Ph}, \mathrm{Ar}_{1}=4-\mathrm{Cl}-\right.$ $\mathrm{Ph}), \mathbf{e}\left(\mathrm{Ar}=4-\mathrm{Me}-\mathrm{Ph}, \mathrm{Ar}_{1}=\mathrm{Ph}\right), \mathbf{f}\left(\mathrm{Ar}=\mathrm{Ar}_{1}=4-\mathrm{Me}-\mathrm{Ph}\right), \mathbf{g}\left(\left(\mathrm{Ar}=4-\mathrm{Me}-\mathrm{Ph}, \mathrm{Ar}_{1}=4-\mathrm{OMe}-\mathrm{Ph}\right)\right.$, $\mathbf{h}\left(\mathrm{Ar}=4-\mathrm{Me}-\mathrm{Ph}, \mathrm{Ar}_{1}=4-\mathrm{Cl}-\mathrm{Ph}\right), \mathbf{i}\left(\mathrm{Ar}=4-\mathrm{Cl}-\mathrm{Ph}, \mathrm{Ar}_{1}=\mathrm{Ph}\right), \mathbf{j}\left(\mathrm{Ar}=4-\mathrm{Cl}-\mathrm{Ph}, \mathrm{Ar}_{1}=4-\mathrm{Me}-\mathrm{Ph}\right), \mathbf{k}$ $\left(\mathrm{Ar}=4-\mathrm{Cl}-\mathrm{Ph}, \mathrm{Ar}_{1}=4-\mathrm{OMe}-\mathrm{Ph}\right), \mathbf{l}\left(\mathrm{Ar}=\mathrm{Ar}_{1}=4-\mathrm{Cl}-\mathrm{Ph}\right)$

Scheme 1. The design of target compounds $4 \mathbf{a}-\mathbf{1}$. 


\section{Results and Discussion}

\subsection{Chemistry}

Our key starting materials, 2-amino-3-cyanonaphthopyranes 1a-c, were synthesized by adopting the method of Zayane et al. [34]. It is a multicomponent reaction of equimolar amounts of arylaldehyde, malononitrile and $\beta$-naphthol at the reflux of a hydroalcoholic solution in the presence of $\mathrm{CuI}$ as a catalyst. Their structures were confirmed on the basis oftheir ${ }^{1} \mathrm{H}$ and ${ }^{13} \mathrm{C}$ NMR spectra and by comparison with literature data [35].

Condensation reaction, of the last precursors, with acetic anhydride in the presence of polyphosphoric acid (PPA) under reflux for $2 \mathrm{~h}$ gives pyrimidinones $\mathbf{2 a}-\mathbf{c}$ in yields ranging from $66 \%$ to $80 \%$. From a mechanistic point of view, the reaction is carried out in two steps. The precursors $1 \mathbf{a}-\mathbf{c}$ react with acetic anhydride to give the non-isolable intermediates $\mathbf{1}^{\prime} \mathbf{a}-\mathbf{c}$ which cyclize to $\mathbf{1}^{\prime \prime} \mathbf{a}-\mathbf{c}$ after nucleophilic attack at the nitrile group. Dimroth-type intramolecular rearrangement $[32,36]$ of the intermediate thus formed leads to pyranopyrimidinones $\mathbf{2 a - c}$, which reacted with propargyl bromide in the presence of sodium hydride in anhydrous DMF at room temperature to give the corresponding $\mathrm{N}$-propargylated dipolarophiles 3a-c in good yields (80-92\%) (Scheme 2) [37].

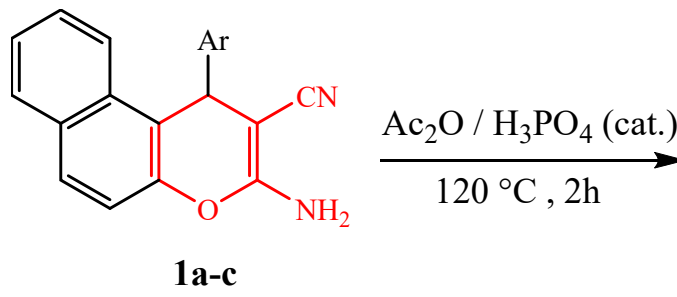

$\mathrm{Ar}=\mathrm{Ph}, 4-\mathrm{Me}-\mathrm{Ph}, 4-\mathrm{Cl}-\mathrm{Ph}$<smiles>CC(C)Nc1oc2ccc3ccccc3c2c1C#N</smiles><smiles>Cc1nc2c(c(=O)[nH]1)C([Al])c1c(ccc3ccccc13)O2</smiles>

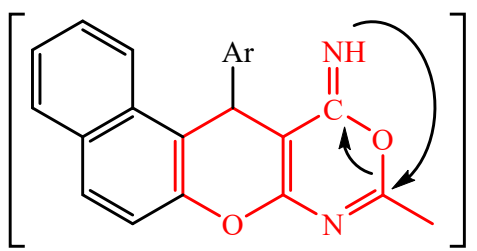

1"a-c<smiles>[Y]C1c2c(ccc3ccccc23)Oc2ccc(C)c([N+](=O)[O-])c2C1[Al]</smiles>

2'a-c<smiles>C#CCn1c(C)nc2c(c1=O)C([Al])c1c(ccc3ccccc13)O2</smiles>

3a-c

Scheme 2. Synthetic pathway to compounds $2 \mathbf{a}-\mathbf{c}$ and $3 \mathbf{a}-\mathbf{c}$.

The formed $N$-propargylatednaphthopyranopyrimidinones $3 a-c$ were identified on the basis of their ${ }^{1} \mathrm{H}$ NMR and ${ }^{13} \mathrm{C}$ NMR spectra. The ${ }^{1} \mathrm{H}$ NMR spectra of these dipolarophiles allows to see, in addition to the signals of the protons introduced by the naphthopyranopyrimidinones $2 \mathbf{a}-\mathbf{c}$, the disappearance of a singlet of the $\mathrm{NH}$ proton at $\delta_{\mathrm{H}}$ 12.60-12.61 and the appearance of three new signals, two doublets of doublets are observed at $\delta_{\mathrm{H}} 4.58-4.61$ and $5.08-5.12(\mathrm{~J}=15.9,2.4 \mathrm{~Hz})$ which were attributed to methylenic protons $\left(\mathrm{CH}_{2}\right)$ and a characteristic triplet of an acetylenic proton observed at $\delta_{\mathrm{H}} 2.29-2.33$ $(J=2.4 \mathrm{~Hz})$. The proximity of methylene to the nitrogen atom bearing four different substituents (hybridized sp3) including its free doulet perfectly conjugated with the carbonyl 
of pyrimidinone is at the origin of the non-isochrony, and thus the non-equivalence of the methylenic protons which logically appear at two different chemical shifts. Moreover, the ${ }^{13} \mathrm{C}$ NMR spectra of these derivatives exhibited the appearance of new signals at $\delta_{\mathrm{C}}$ 31.7-32.7, 71.8-72.4 and 75.3-76.1 relative to new carbons $C_{4^{\prime}}, C_{5^{\prime}}$ and $C_{6^{\prime}}$ introduced by the propargyl moiety, respectively.

In order to access, via 1,3-dipolar cycloaddition reaction as shown in Scheme 3, to the new expected hybrid molecules $4 \mathbf{a}-\mathbf{l}$, the $N$-propargylated derivatives $\mathbf{3 a}-\mathbf{c}$ were treated with various arylnitrile oxides, under conventional heating in refluxing DMF for 8-12 $\mathrm{h}$ (Method A) or under microwave irradiation in DMF for 3 to $5 \mathrm{~min}$ (Method B), both in the presence of copper(I) catalyst and $\mathrm{Et}_{3} \mathrm{~N}$ as a base.

Until now, copper catalyzed nitrile oxide-alkyne click chemistry (CuAAC) is one of the methods of choice for regiospecific access to 3,5-disubstituted isoxazole derivatives [38].<smiles>[R]c1ccc(C2c3c(nc(C)n(CC#C)c3=O)Oc3ccc4ccccc4c32)cc1</smiles>

3a-c<smiles>[R]c1ccc(/C(Cl)=N/O)cc1</smiles><smiles>[R][R]Cc1cc(-c2ccc([R])cc2)no1</smiles>

\section{4a-I}

Scheme 3. Synthesis of 3,5-isoxazole derivatives $4 \mathbf{a}-\mathbf{- 1}$.

From a mechanistic point of view, the formation of copper(I) acetylide I (step A) occurs through a $\pi$-alkyne copper complex intermediate. The $\pi$-coordination of alkyne to copper significantly acidifies terminal hydrogen of the alkyne, bringing it into the proper range to be deprotonated in presence of TEA and resulting in the formation of a $\sigma$-acetylide with a second copper(I) atom. The added aryl nitrile oxide is then activated by coordination to copper (step B), thus forming the intermediate II. In the next step (C), the formation of the first $\mathrm{C}-\mathrm{O}$ bond takes place, and a strained copper metallacycle III forms. This intermediate undergoes a rearrangement to lead to copper(I) isoxazole intermediate IV (step D), which in the presence of another molecule of alkyne gives the desired isoxazole while regenerating intermediate I (step E) (Scheme 4).

This reaction sequence generates the new hybrid molecules $4 a-1$ in moderate (method A/58-69\%) to excellent yields (method B/91-97\%). The absence of any other compound in the reaction mixture implies the strong regiospecificity of this reaction.

These resulting 3,5-regioisomers were confirmed from the NOE H-5 $5_{\text {isoxazole }} / \mathrm{H}_{\text {methylene }}$ and $\mathrm{H}-5_{\text {isoxazole }} / \mathrm{H}_{\text {arom }}$, and the non-observation of any $\mathrm{NOE} \mathrm{H}_{\text {methylene }} / \mathrm{H}_{\text {arom }}$. Thus, this 3,5-regiospecificity was explained by the uses of copper(I) catalyst.

The comparison of the obtained results shown in Table 1 from the conventional heating method (method A) and those from the MW-assisted synthesis way (method B) showed in all cases much shorter reaction times and higher yields were achieved under MW irradiation compared to classical heating. 


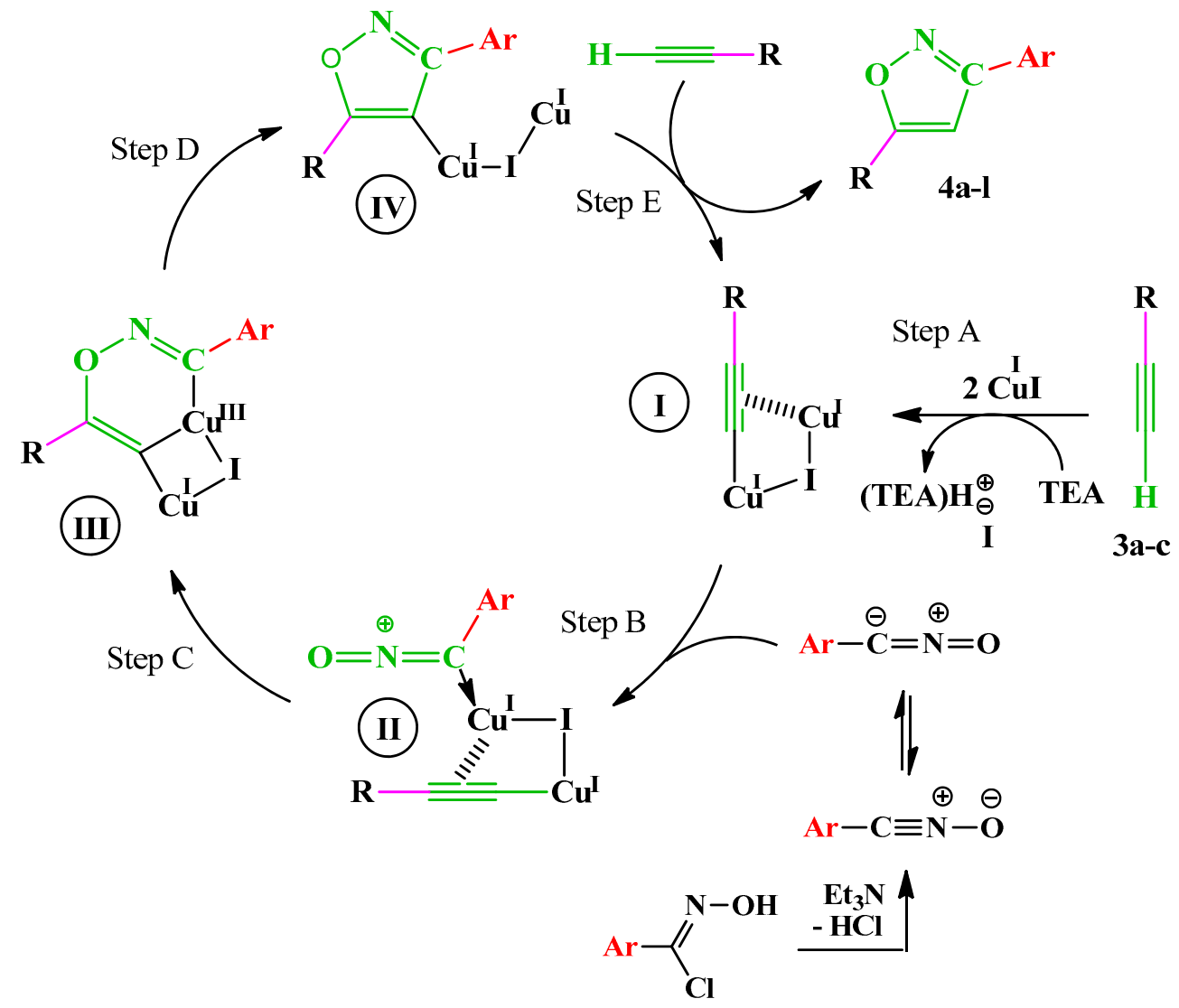

Scheme 4. Proposed mechanism for the formation of compounds 4a-1.

The structures of the newly prepared compounds $4 \mathbf{a}-\mathbf{1}$ were raised on the basis of their spectroscopic measurements. In fact, compared to compounds 3 , the ${ }^{1} \mathrm{H}$ NMR spectra of isoxazoles derivatives $4 \mathbf{a}-\mathbf{l}$ indicate the disappearance of the signal at $\delta_{\mathrm{H}} 2.30-2.32$ relative to the terminal acetylenic proton and the appearance of a new singlet at $\delta_{\mathrm{H}} 6.50-6.51(\mathrm{~s}, 1 \mathrm{H})$ attributable to $\mathrm{H}_{2^{\prime}}$ of the isoxazole ring, in addition to signals at $\delta_{\mathrm{H}} 6.92-7.98$ attributable to the protons of the aromatic moiety linked to the isoxazole system. Moreover, the ${ }^{13} \mathrm{C} N M R$ spectra reinforced the structures of $4 a-1$ by showing the signals of the formed isoxazole moiety, as well as those from the dipolarophiles $\mathbf{3 a - c}$.

The ES-HRMS of compounds 3 and $\mathbf{4}$ showed the correct protonated molecular ion peaks $[\mathrm{M}+\mathrm{H}]^{+}$that complied with the proposed structures.

Table 1. Comparison between the conventional heating procedure (method A) and microwave irradiation (method B) for the synthesis of compounds $4 \mathbf{a}-\mathbf{1}$.

\begin{tabular}{|c|c|c|c|c|c|c|}
\hline Product & $\mathbf{R}$ & $\mathbf{R}_{1}$ & Time (h) & Yield $(\%)^{a}$ & Time (min) & Yield $(\%)^{b}$ \\
\hline $4 a$ & $\mathrm{H}$ & $\mathrm{H}$ & 8 & 69 & 5 & 97 \\
\hline $4 b$ & $\mathrm{H}$ & $\mathrm{Me}$ & 12 & 63 & 3 & 93 \\
\hline $4 c$ & $\mathrm{H}$ & $\mathrm{OMe}$ & 10 & 62 & 5 & 92 \\
\hline $4 d$ & $\mathrm{H}$ & $\mathrm{Cl}$ & 8 & 60 & 5 & 92 \\
\hline $4 e$ & $\mathrm{Me}$ & $\mathrm{H}$ & 12 & 67 & 3 & 95 \\
\hline $4 f$ & $\mathrm{Me}$ & $\mathrm{Me}$ & 12 & 65 & 3 & 96 \\
\hline $4 g$ & $\mathrm{Me}$ & $\mathrm{OMe}$ & 8 & 64 & 3 & 94 \\
\hline $4 h$ & $\mathrm{Me}$ & $\mathrm{Cl}$ & 12 & 68 & 3 & 97 \\
\hline $4 i$ & $\mathrm{Cl}$ & $\mathrm{H}$ & 9 & 62 & 5 & 93 \\
\hline $4 j$ & $\mathrm{Cl}$ & $\mathrm{Me}$ & 8 & 58 & 3 & 91 \\
\hline $4 k$ & $\mathrm{Cl}$ & $\mathrm{OMe}$ & 8 & 67 & 3 & 96 \\
\hline 41 & $\mathrm{Cl}$ & $\mathrm{Cl}$ & 12 & 60 & 3 & 92 \\
\hline
\end{tabular}

${ }^{\mathrm{a}}$ Isolated yield after column chromatography. ${ }^{\mathrm{b}}$ Microwaveirradiation $(250 \mathrm{~W})$. 


\subsection{Molecular Docking Study}

By studying the binding pocket of the SARS-CoV-2 $\mathrm{M}^{\text {pro }}$, it was found that the cocrystallized native inhibitor (N3) is located inside the pocket of the main protease receptor asymmetrically. The N3 ligand is a designed inhibitor for SARS-CoV-2 Mpro that was built from amino acids based on the $\mathrm{M}^{\text {pro }}$ pocket amino acids and cannot used medicinally. The main residues in this pocket were HIS-41, MET-49, PHE-140, GLY-143, HIS-164, MET165, GLU-166, LEU-167, PRO-168, HIS-172, GLN-189, THR-190 and ALA-191.

Molecular docking of the synthesized molecules (4a-1) and N3 inhibitor into the main protease binding site was performed. The binding energies and interaction details (number of interactions, number of interacting amino acids, interacting amino acids and hydrogen bonds) of ligands with the target enzyme are presented in Table 2.

All compounds were perfectly placed in the active site by variable scores and binding interactions with the amino acids of the receptor pocket. From the docking results (Table 2), All the tested compounds (4a-1) achieved promising binding scores ranging from -7.6 to $-8.9 \mathrm{kcal} / \mathrm{mol}$, compared to the docked co-crystallized N3 inhibitor with a binding score of $-7.0 \mathrm{kcal} / \mathrm{mol}$. The synthesized compounds $(\mathbf{4 a}-\mathbf{1})$ showed a much higher binding affinity towards Mpro enzyme (PDB: 6LU7) than N3.

It is worth mentioning that, especially for compounds $4 \mathbf{a}, 4 \mathbf{e}$ and $4 \mathbf{i}$, the obtained binding modes were quite similar to that of the docked N3 inhibitor, as depicted in Table 3. Moreover, these three selected compounds exhibited binding scores of $-8.4,-8.5$ and $-8.5 \mathrm{kcal} / \mathrm{mol}$, respectively, higher than of the docked co-crystallized N3 inhibitor $(-7.0 \mathrm{kcal} / \mathrm{mol})$ (Table 2).

The docked N3 inhibitor was stabilized inside the SARS-CoV-2 M ${ }^{\text {pro }}$ pocket through a three hydrogen bonds formation with GLY-143, HIS-164 and GLN-198 amino acids with the bond lengths of $2.96,2.67$ and $3.25 \AA$, respectively. Additionally, it formed a Pi-alkyl bond with MET-165 (bond length: $5.05 \AA$ ) and two alkyl interactions with HIS-41 (bond length: $4.28 \AA$ ) and MET- 49 (bond length: $4.45 \AA$ ) residues. On the other side, the compound $4 \mathrm{a}$ fitted inside the binding site of the SARS-CoV-2 $\mathrm{M}^{\text {pro }}$ by two hydrogen bonds formation, with GLY-143 and GLU-166 at 3.37 and $3.05 \AA$, respectively, with an additional carbon hydrogen bond with ASN-142 residue (bond length: $3.38 \AA$ ) and two Pi-sulfur interactions with MET-49 (bond length: $5.38 \AA$ ) andMET-165(bond length: $5.23 \AA$ ). Moreover, the compound 4e showed a hydrogen bond with the GLY-143 amino acid at $3.19 \AA$ A. Additionally, it showed a carbon hydrogen bond with ASN-142 residue (bond length: $3.39 \AA$ ) and two Pi-sulfur interactions with MET-49 (bond length: $5.11 \AA$ ) and MET-165 (bond length: $5.75 \AA$ ). The compound $4 \mathbf{i}$ formed a hydrogen bond, a carbon hydrogen bond and two Pi-sulfur interactions with the previously mentioned four amino acids as well. It formed a hydrogen bond with GLY-143 at $3.21 \AA$, a carbon hydrogen bond with ASN-142 at $3.46 \AA$ and two Pi-sulfur interactions with MET-49 and MET-165 at 5.06 and $5.81 \AA$, respectively.

Although compounds $4 \mathbf{k}, 4 \mathbf{h}$ and $4 \mathbf{j}$ did not exhibit very comparable interactions to those of N3 towards SARS-CoV-2 Mpro, they, on the other hand, exhibited lower binding energy $(-8.9,-8.5$ and $-8.4 \mathrm{kcal} / \mathrm{mol}$, respectively) (Table 2$)$. This finding can be explained, in part, by the nature of interactions between these compounds and the amino acids that constitute SARS-CoV-2 Mpro (Table 4). Indeed, the compound $4 \mathbf{k}$ formed a hydrogen bond with THR-26 (bond length: $3.19 \AA$ ), three Pi-alkyl bonds with MET-49 (bond length: $5.39 \AA$ ), MET-165 (bond length: $4.82 \AA$ ) and PRO-168 (bond length: $4.53 \AA$ ), a Pi-sulfur interaction with CYS-145 (bond length: $5.10 \AA$ ) and a Pi-sigma interaction with HIS-41 (bond length: $3.71 \AA$ ). Moreover, the derivative $4 \mathrm{~h}$, was engaged in a hydrogen bond, two Pi-donor hydrogen bonds, a Pi-sulfur interaction, two alkyl interactions and a Pi-alkyl bond with residues GLY-143 (bond length: $2.96 \AA$ ), ASN-142 (bond length: $3.65 \AA$ ), GLY-143 (bond length: $3.57 \AA$ ), CYS-145 (bond length: $4.79 \AA$ ), HIS-41 (bond length: $4.09 \AA$ ), CYS-145 (bond length: $4.48 \AA$ ) and PRO-168 (bond length: $4.88 \AA$ ), respectively. The compound $4 \mathbf{j}$ interacts with in many amino acids of the main protease of COVID-19 $\left(\mathrm{M}^{\text {pro }}\right)$ via two Hydrogen Bond, Pi-sigma interaction and a two Pi-alkyl bond with the side chain residues 
GLY-143 (bond length: $3.19 \AA$ A), GLU-166 (bond length: $3.15 \AA$ A), MET- 49 (bond length: $3.95 \AA$ ), CYS-145 (bond length: $5.25 \AA$ ), HIS-163 (bond length: $4.98 \AA$ ), respectively.

It is important to mention that the nature of the substituents allows the molecule to be placed into space in a well-defined conformation. Indeed, these substituents with different sizes promote or disadvantage possible free rotations, they also increase or decrease the electron density of certain groups essentially the aromatic ones by their indicative and/or mesomeric electronic effects. The spatial arrangement of the two benzene rings in compounds $4 a-1$ depends on the nature of their substituents ( $R$ and $R_{1}$ ). This arrangement can, in certain cases, inhibit the delocalization of the electronic doublets by mainly mesomeric effects towards the outside of the ring (case of the aromatic system carried by the isoxazole nucleus), which influences the interaction of these aromatic systems with certain amino acids. Moreover, the $\mathrm{R}$ and $\mathrm{R}_{1}$ substituents do not need to engage in direct interactions with amino acids, but their sizes and electronic effects require special interactions of the corresponding aromatic rings with special amino acids. As mentioned in Table 3, the benzene ring at position C- 6 of the pyran moiety and that carried by isoxazole both unsubstituted in 4a exhibit Pi-sulfur interactions with MET-49 (bond length: $5.38 \AA$ ) andMET-165 (bond length: $5.23 \AA$ ), respectively. The same observation was noted with compounds $4 \mathbf{e}$ and $4 \mathbf{i}$ where the aromatic ring carried by the pyran is para-methylated and para-chlorinated, respectively and the benzene ring carried by the isoxazole in both dervivatives is unsubstituted. This result can be explained by the effect of the size of the methyl group and the chlorine atom on the spatial arrangement of the aromatic ring throughout the molecule. In addition, the inductive donor effect $(+\mathrm{I})$ exerted by the methyl group and the two opposite electronic effects (-I) and (+ M) exerted by the chlorine atom appear to lead to practically the same result. It was observed that in the case of compound $4 \mathrm{~h}$, the benzenic nucleus attached to an isoxazole carrying in para position a chlorine atom $\left(\mathrm{R}_{1}\right)$ exerts two Pi-donor Hydrogen bonds interactions with ASN-142 (bond length: $3.65 \AA$ ). These types of interactions were not observed in the rest of the products with other $R$ and $R_{1}$ which proves that the nature of these two substituents give the entire molecule a well-defined conformation which also guarantees well-defined interactions. With $\mathrm{R}=\mathrm{Cl}$ and $\mathrm{R}_{1}=\mathrm{OMe}$, the compound $4 \mathbf{k}$, takes a new conformation which allows, among other things, the OMe group to engage in a hydrogen bond with THR-26 (bond length: $3.19 \AA$ ).

According to our findings, the tested compounds, in particular $4 \mathbf{a}, 4 \mathbf{e}, \mathbf{4 h}, \mathbf{4 i}, 4 \mathbf{j}$ and $4 \mathbf{k}$, could effectively act as novel antiviral agents against SARS-CoV-2.

Table 2. Binding energy $(\mathrm{kcal} / \mathrm{mol})$ and interaction detail of compounds $\mathbf{4 a - 1}$ docked in the active site of $\mathrm{M}^{\text {pro }}$ enzyme (PDB: 6LU7).

\begin{tabular}{|c|c|c|}
\hline Compound & Binding Energy (kcal/mol) & $\begin{array}{l}\text { Interaction Detail: } \\
\text { NI/NIAA: IAA }\end{array}$ \\
\hline $4 a$ & -8.4 & 5/5: MET-49, ASN-142, GLY-143 *, MET-165, GLU-166* \\
\hline $4 b$ & -7.7 & 8/4: MET-165, GLU-166 *, PRO-168, ALA-191 \\
\hline $4 c$ & -7.7 & 7/5: MET-49, GLY-143 *, CYS-145, HIS-163, GLU-166 \\
\hline $4 d$ & -7.7 & 8/4: MET-165, GLU-166 *, PRO-168, ALA-191 \\
\hline $4 e$ & -8.5 & 4/4: MET- 49, ASN-142, GLY-143*, MET-165 \\
\hline $4 f$ & -7.9 & 8/4: MET-165, GLU-166 *, PRO-168, ALA-191 \\
\hline $4 \mathrm{~g}$ & -7.6 & 6/5: MET- 49, GLY-143 *, CYS-145, HIS-163, GLU-166 \\
\hline $4 \mathrm{~h}$ & -8.5 & 7/5: HIS-41, ASN-142, GLY-143 *, CYS-145, PRO-168 \\
\hline $4 \mathbf{i}$ & -8.5 & 4/4: MET- 49, ASN-142, GLY-143 *, MET-165 \\
\hline $4 j$ & -8.4 & 5/5: MET- 49, GLY-143 *, CYS-145, HIS-163, GLU-166 * \\
\hline $4 \mathbf{k}$ & -8.9 & 6/6: THR-26 *, HIS-41, MET-49, CYS-145, MET-165, PRO-168 \\
\hline 41 & -7.7 & 7/3: MET-165, GLU-166 *, PRO-168 \\
\hline N3 & -7.0 & 6/6: HIS-41, MET-49, GLY-143 *, HIS-164 *, MET-165, GLN-189 * \\
\hline
\end{tabular}

NI: number of interactions, NIAA: number of interacting amino acids, IAA: interacting amino acids, ${ }^{*}=$ One hydrogen bond. 
Table 3. 3D representations showing the binding interactions and positioning between the three promising tested compounds (4a, $4 \mathbf{e}$ and $4 \mathbf{i}$ ) and the N3-binding pocket in comparison to the docked N3 inhibitor.

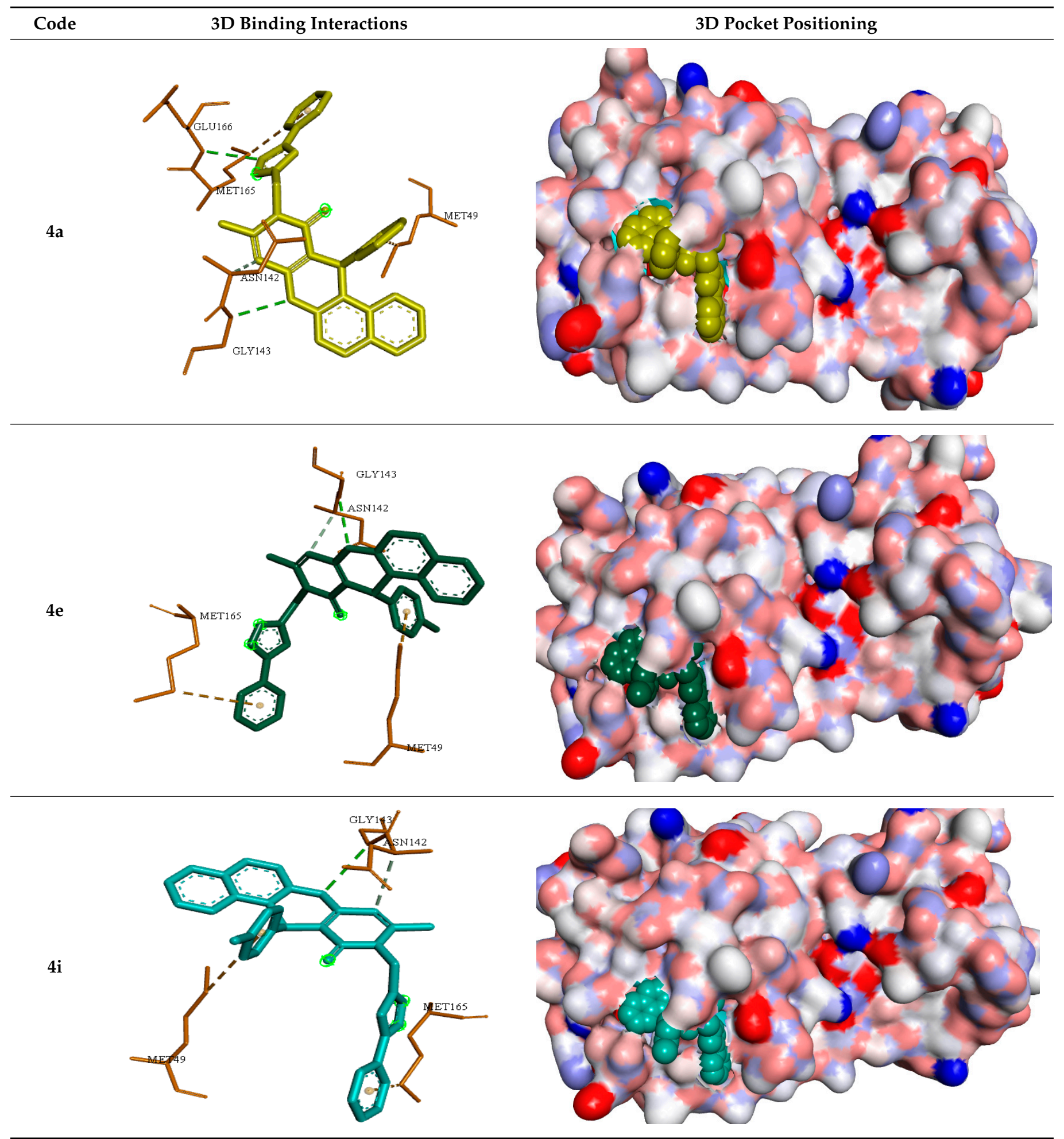


Table 3. Cont

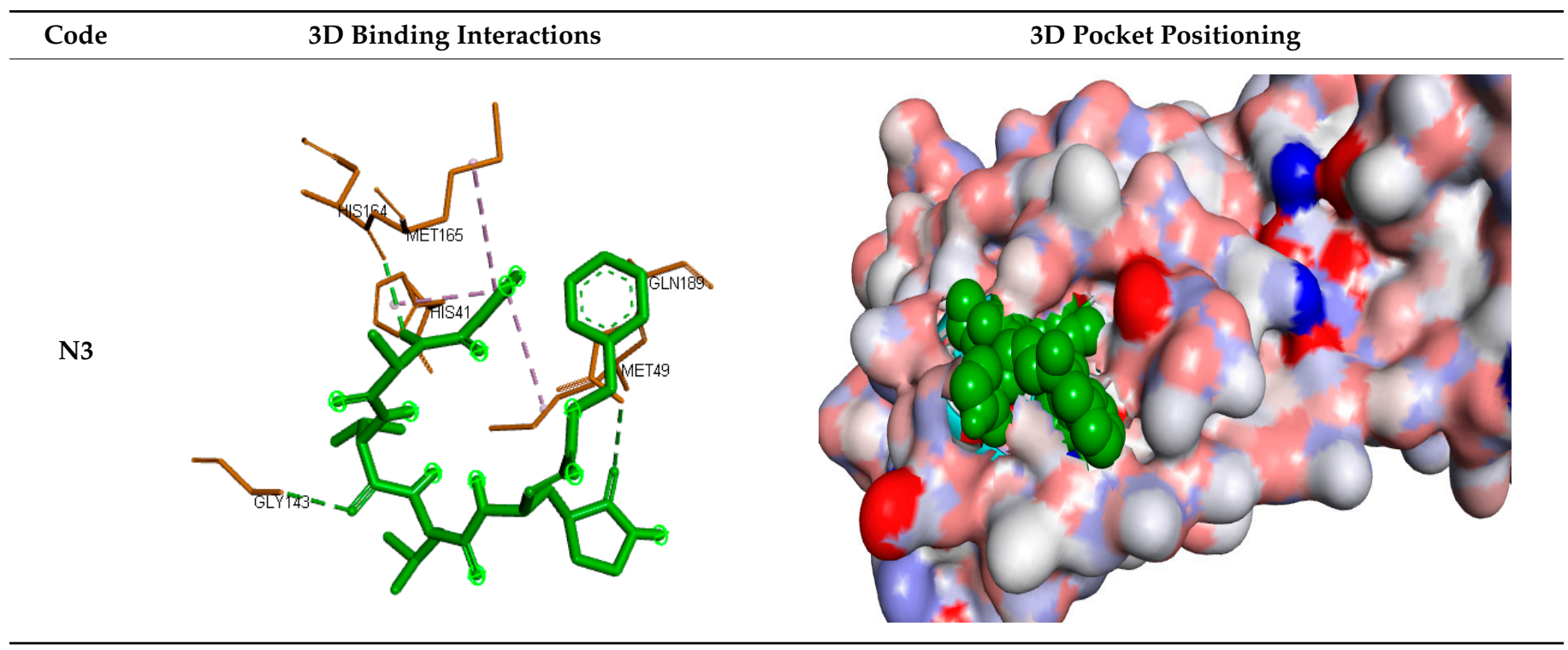

Table 4. 3D representations showing the binding interactions and positioning between the three promising tested compounds (4k, $4 \mathbf{h}$ and $4 \mathbf{j})$ and the N3-binding pocket.

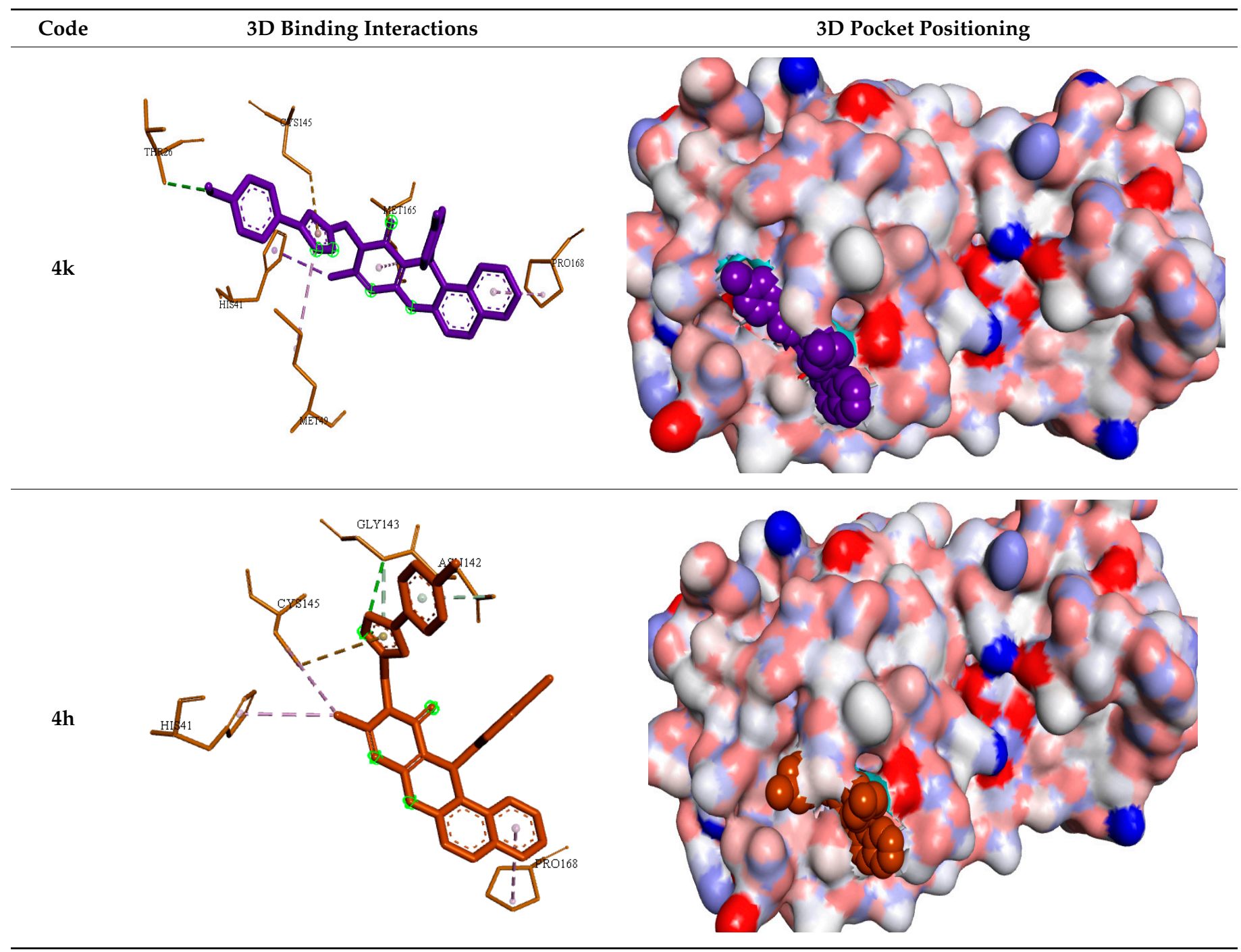


Table 4. Cont.

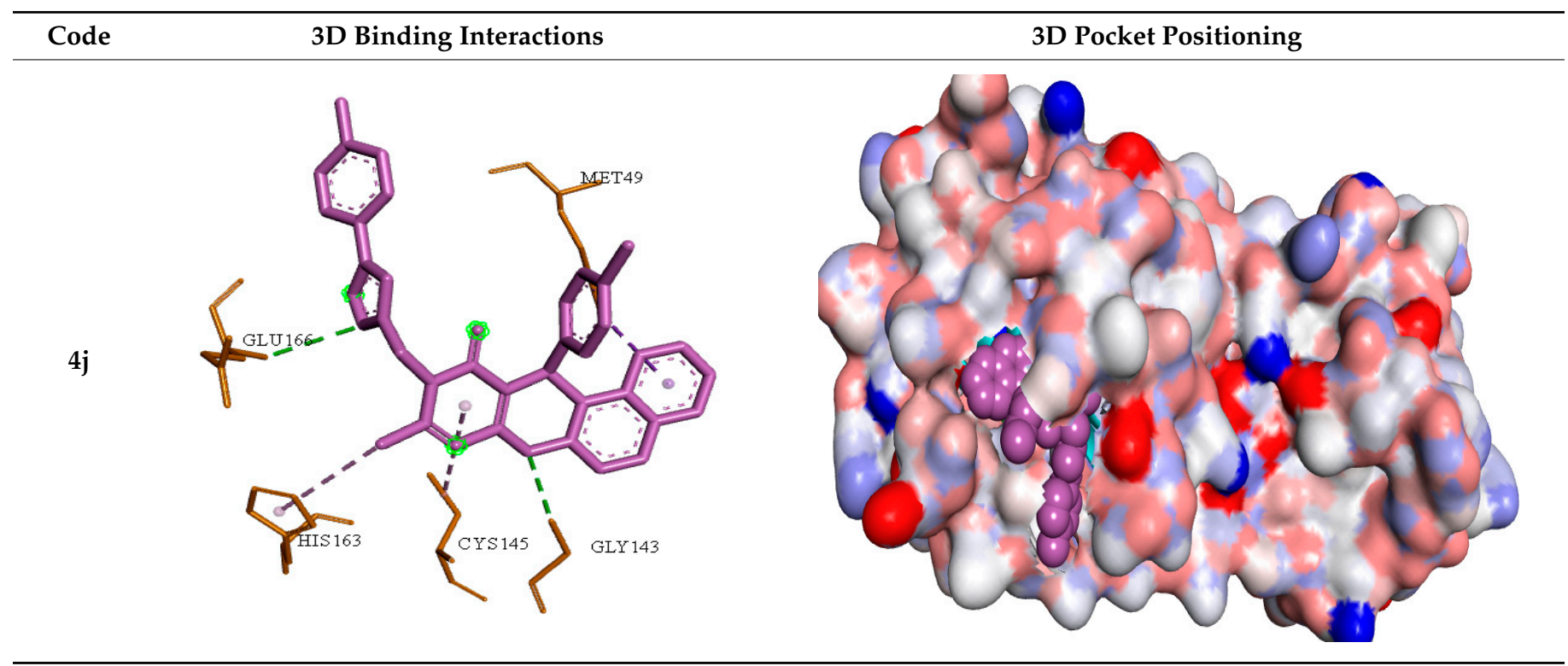

3. Methods and Materials

\subsection{Chemistry}

\subsubsection{General Experimental Procedures}

All synthesis reactions were checked by TLC using aluminium sheets of silica gel $60 \mathrm{~F}_{254}, 0.2 \mathrm{~mm}$. Melting points were measured on an electrothermal 9002 apparatus and were reported uncorrected. NMR spectra were run on a Bruker AC-300 spectrometer at $300 \mathrm{MHz}\left({ }^{1} \mathrm{H}\right)$ and $75 \mathrm{MHz}\left({ }^{13} \mathrm{C}\right)$. All chemical shifts were reported as $\delta$ values (ppm) relative to residual non-deuterated solvent. Mass spectra were recorded with HRMSES using the reflectron mode in the positive ion mode. Microwave-assisted synthesis was peformed in a Start Synth multimode microwave instrument producing controlled irradiation at $2.45 \mathrm{GHz}$ (Milestone S.r.l., Sorisole, Italy). The device is equipped with an industrial magnetron and a microwave diffuser providing a continuous microwave output power from 0 to $1400 \mathrm{~W}$. An open reaction vessel was employed in all reactions.

The starting materials 1 and $\mathbf{2}$ were prepared according to the literature [32].

3.1.2. General Procedure for the Preparation of Naphthopyranopyrimidinone N-Propargylated Derivatives 3a-c

$1 \mathrm{mmol}$ of naphthopyranopyrimdinone $\mathbf{2 a}-\mathbf{c}$ was dissolved in $15 \mathrm{~mL}$ of anhydrous DMF then 2 equivalents of sodium hydride $(\mathrm{NaH})$ were added and the reaction mixture was stirred at room temperature under an argon atmosphere for $30 \mathrm{~min}$; afterwards, $1.5 \mathrm{eq}$ of propargyl bromide was added slowly, and the mixture was stirred for another $1.5 \mathrm{~h}$ under positive atmosphere of argon. Upon completion of the reaction, monitored by TLC, we added distilled water and the formed precipitate was collected by filtration, washed with water and purified by flash column chromatography on silica gel (EtOAc/PE, 1:1, as an eluent).

Compound 3a: 3-methyl-6-phenyl-4-(prop-2-yn-1-yl)-10H-naphtho[2,1-b]pyrano[2,3d]pyrimidin-11(12H)-one

Brown solid, yield 88\%, mp 193-195 ${ }^{\circ} \mathrm{C} .{ }^{1} \mathrm{H}$ NMR $\left(300 \mathrm{MHz} ; \mathrm{CDCl}_{3}\right): \delta(\mathrm{ppm})=2.22$ $\left(\mathrm{s}, 3 \mathrm{H}, \mathrm{H}_{9^{\prime}}\right) ; 2.32\left(\mathrm{t}, 1 \mathrm{H}, \mathrm{H}_{6^{\prime \prime}}{ }^{\prime}, J=2.4 \mathrm{~Hz}\right) ; 4.69\left(\mathrm{dd}, 1 \mathrm{H}, \mathrm{H}_{4^{\prime \prime}{ }^{\prime}{ }^{\prime}} J=2.4 \mathrm{~Hz}, J=17.4 \mathrm{~Hz}\right) ; 5.12$ $\left(\mathrm{dd}, 1 \mathrm{H}, \mathrm{H}_{4^{\prime \prime} \mathrm{b}^{\prime}} \mathrm{J}=2.4 \mathrm{~Hz}, J=17.4 \mathrm{~Hz}\right) ; 5.79\left(\mathrm{~s}, 1 \mathrm{H}, \mathrm{H}_{6}\right) ; 7.03\left(\mathrm{~d}, 2 \mathrm{H}, \mathrm{H}_{2^{\prime}, 6^{\prime}}, J=8.1 \mathrm{~Hz}\right) ; 7.43$ (m, 6H, $\left.\mathrm{H}_{\text {arom. }}\right) ; 7.79$ (d, 2H, $\left.\mathrm{H}_{11,12}, J=7.6 \mathrm{~Hz}\right) ; 7.92\left(\mathrm{~d}, 1 \mathrm{H}, \mathrm{H}_{7}, J=8.1 \mathrm{~Hz}\right) .{ }^{13} \mathrm{C} \mathrm{NMR}$ $\left(75 \mathrm{MHz} ; \mathrm{CDCl}_{3}\right): \delta(\mathrm{ppm})=23.2,32.7,35.3,71.9,75.3,102.2,116.1,117.0,123.6,124.4,126.6$, 127.7, 127.9, 128.6, 128.9, 130.5, 131.2, 135.8, 140.6, 147.5, 157.3, 158.9, 161.0. ESI-HRMS $[\mathrm{M}+\mathrm{H}]^{+}$calcd. For $\left(\mathrm{C}_{25} \mathrm{H}_{18} \mathrm{~N}_{2} \mathrm{O}_{2}\right)^{+}: 379.1446$, found: 379.1456 . 
Compound 3b: 3-methyl-4-(prop-2-yn-1-yl)-6-(p-tolyl)-10H-naphtho[2,1-b]pyrano[2,3d]pyrimidin-11(12H)-one

Brown solid, yield 92\%, mp 192-194 ${ }^{\circ} \mathrm{C} .{ }^{1} \mathrm{H}$ NMR $\left(300 \mathrm{MHz} ; \mathrm{CDCl}_{3}\right): \delta(\mathrm{ppm})=2.22$ $\left(\mathrm{s}, 3 \mathrm{H}, \mathrm{H}_{9^{\prime}}\right) ; 2.29\left(\mathrm{t}, 1 \mathrm{H}, \mathrm{H}_{6^{\prime \prime}}, J=2.4 \mathrm{~Hz}\right) ; 2.67\left(\mathrm{~s}, 3 \mathrm{H}, \mathrm{H}_{4^{\prime}}\right) ; 4.58\left(\mathrm{dd}, 1 \mathrm{H}, \mathrm{H}_{4^{\prime \prime}} \mathrm{a}^{\prime}, J=2.4 \mathrm{~Hz}\right.$, $J=17.4 \mathrm{~Hz}) ; 5.08\left(\mathrm{dd}, 1 \mathrm{H}, \mathrm{H}_{4^{\prime \prime}} \mathrm{b}, J=2.4 \mathrm{~Hz}, J=17.4 \mathrm{~Hz}\right) ; 5.87\left(\mathrm{~s}, 1 \mathrm{H}, \mathrm{H}_{6}\right) ; 7.03\left(\mathrm{~d}, 2 \mathrm{H}, \mathrm{H}_{3^{\prime}, 5^{\prime}}\right.$, $J=8.1 \mathrm{~Hz}) ; 7.38\left(\mathrm{~m}, 5 \mathrm{H}, \mathrm{H}_{\text {aromatic }}\right) ; 7.82\left(\mathrm{~d}, 2 \mathrm{H}, \mathrm{H}_{11}, 12, J=7.4 \mathrm{~Hz}\right) ; 7.92\left(\mathrm{~d}, 1 \mathrm{H}, \mathrm{H}_{7}, J=8.1 \mathrm{~Hz}\right)$ ${ }^{13} \mathrm{C}$ NMR $\left(75 \mathrm{MHz} ; \mathrm{CDCl}_{3}\right): \delta(\mathrm{ppm})=20.4,22.0,32.7,35.9,72.4,76.1,101.1,116.1,116.9$, 123.2, 124.4, 126.6, 127.8, 127.9, 128.6, 128.8, 130.5, 131.0, 135.8, 140.2, 147.5, 157.3, 158.9, 160.9. ESI-HRMS [M+H] $]^{+}$calcd. For $\left(\mathrm{C}_{26} \mathrm{H}_{19} \mathrm{~N}_{2} \mathrm{O}_{2}\right)^{+}: 392.1524$, found: 392.1531 .

Compound 3c: 6-(4" -chlorophenyl)-3-methyl-4-(prop-2-yn-1-yl)-10H-naphtho[2,1$b$ ]pyrano[2,3-d]pyrimidin-11(12H)-one

Brown solid, yield $80 \%, \mathrm{mp} 194-196{ }^{\circ} \mathrm{C} .{ }^{1} \mathrm{H}$ NMR $\left(300 \mathrm{MHz} ; \mathrm{CDCl}_{3}\right): \delta(\mathrm{ppm})=2.24$ (s, 3H, $\left.\mathrm{CH}_{3}\right) ; 2.33\left(\mathrm{t}, 1 \mathrm{H}, \mathrm{H}_{6^{\prime \prime}}, J=2.4 \mathrm{~Hz}\right) ; 4.62\left(\mathrm{dd}, 1 \mathrm{H}, \mathrm{H}_{4^{\prime \prime}}, J=2.4 \mathrm{~Hz}, J=17.4 \mathrm{~Hz}\right) ; 5.18$ $\left(\mathrm{dd}, 1 \mathrm{H}, \mathrm{H}_{4^{\prime \prime}}, J=2.4 \mathrm{~Hz}, J=17.4 \mathrm{~Hz}\right) ; 5.85\left(\mathrm{~s}, 1 \mathrm{H}, \mathrm{H}_{6}\right) ; 7.05\left(\mathrm{~d}, 2 \mathrm{H}, \mathrm{H}_{2^{\prime}, 6^{\prime}}, J=8.1 \mathrm{~Hz}\right) ; 7.40$ $\left(\mathrm{m}, 5 \mathrm{H}, \mathrm{H}_{\text {aromatic }}\right) ; 7.82\left(\mathrm{~d}, 2 \mathrm{H}, \mathrm{H}_{11,12}, J=7.4 \mathrm{~Hz}\right) ; 7.90\left(\mathrm{~d}, 1 \mathrm{H}, \mathrm{H}_{7}, J=8.1 \mathrm{~Hz}\right) .{ }^{13} \mathrm{C}$ NMR $\left(75 \mathrm{MHz} ; \mathrm{CDCl}_{3}\right): \delta(\mathrm{ppm})=22.6,31.7,35.4,71.8,75.4,102.4,116.1,116.9,123.2,124.4,126.6$, 127.8, 127.9, 128.7, 128.9, 130.4, 131.0, 136.8, 140.4, 146.5, 156.3, 157.9, 161.3. ESI-HRMS $[\mathrm{M}+\mathrm{H}]^{+}$calcd. For $\left(\mathrm{C}_{25} \mathrm{H}_{16} \mathrm{ClN}_{2} \mathrm{O}_{2}\right)^{+}: 412.0978$, found: 412.0989 .

\subsubsection{General Procedure for the Preparation of Isoxazoles Derivatives 4a-1}

Method A (conventional method): Alkynes 3a-c $(1 \mathrm{mmol})$ and appropriate hydroximyl chloride ( $2 \mathrm{mmol}$ ) were dissolved in $3 \mathrm{~mL}$ DMF. Cuprous iodide (I) (0.1 equiv) was added with stirring followed by $\mathrm{Et}_{3} \mathrm{~N}(0.4 \mathrm{mmol})$ at room temperature. The mixture was refluxed for 8-12 $\mathrm{h}$. After cooling, the mixture was diluted with water and then extracted with ethyl acetate $(3 \times 30 \mathrm{~mL})$. The organic layer was dried over $\mathrm{Na}_{2} \mathrm{SO}_{4}$. After the removal of solvent in vacuo, the resulting residue was purified by silica gel column chromatography eluted with dichloromethane to obtain the desired new products (4a-1).

Method B (microwave-assisted): Alkynes $3 \mathbf{a}-\mathbf{c}(1 \mathrm{mmol})$ and appropriate hydroximyl chloride ( $2 \mathrm{mmol}$ ) were dissolved in $3 \mathrm{~mL}$ DMF. Cuprous iodide (I) (0.1 equiv) was added with stirring followed by $\mathrm{Et}_{3} \mathrm{~N}(0.4 \mathrm{mmol})$ at room temperature. The reaction mixture was then subjected to microwave irradiations at 250 Watts for 3-5 min, after which it was diluted with water and then extracted with ethyl acetate $(3 \times 30 \mathrm{~mL})$. The organic layer was dried over $\mathrm{Na}_{2} \mathrm{SO}_{4}$. After removal of solvent under reduced pressure, the resulting residue was purified by silica gel column chromatography eluted with dichloromethane to abtain the desired new products $(\mathbf{4 a}-\mathbf{1})$.

Compound 4a: 3-methyl-6-phenyl-4-(( $3^{\prime \prime}-$ phenylisoxazol-5"-yl)methyl)-10H-naphtho pyrano[2,3- $d$ ]pyrimidin-11(12H)-one

White solid, yield $97 \%$, mp $148-150{ }^{\circ} \mathrm{C} .{ }^{1} \mathrm{H}$ NMR $\left(300 \mathrm{MHz} ; \mathrm{CDCl}_{3}\right): \delta(\mathrm{ppm})=2.72$ $\left(\mathrm{s}, 3 \mathrm{H}, \mathrm{H}_{9^{\prime}}\right) ; 5.13\left(\mathrm{~d}, 1 \mathrm{H}, \mathrm{H}_{4^{\prime \prime}}, J=15.9 \mathrm{~Hz}\right) ; 5.57\left(\mathrm{~d}, 1 \mathrm{H}, \mathrm{H}_{4^{\prime \prime}}, J=15.9 \mathrm{~Hz}\right) ; 5.87(\mathrm{~s}, 1 \mathrm{H}$, $\left.\mathrm{H}_{6}\right) ; 6.54\left(\mathrm{~s}, 1 \mathrm{H}, \mathrm{H}_{2^{\prime \prime}}\right) ; 7.19$ (d, 2H, $\left.\mathrm{H}_{2^{\prime \prime \prime}, 6^{\prime \prime \prime},}, J=8.4 \mathrm{~Hz}\right) ; 7.26-7.49$ (m, 9H, $\left.\mathrm{H}_{\text {arom }}\right) ; 7.70-7.72$ $\left(\mathrm{m}, 2 \mathrm{H}, \mathrm{H}_{\text {arom }}\right) ; 7.79-7.83\left(\mathrm{~m}, 3 \mathrm{H}, \mathrm{H}_{\text {arom }}\right) .{ }^{13} \mathrm{C} \mathrm{NMR}\left(75 \mathrm{MHz} ; \mathrm{CDCl}_{3}\right): \delta(\mathrm{ppm})=22.4,35.7$, $39.2,100.7,101.7,115.2,116.9,122.9,124.6,126.3,126.7,127.8,128.0,128.4,129.2,129.3$, 129.7, 130.3, 131.1, 132.1, 141.5, 147.5, 157.6, 161.3, 162.4, 165.6. ESI-HRMS [M+H] ${ }^{+}$calcd. For $\left(\mathrm{C}_{32} \mathrm{H}_{23} \mathrm{~N}_{3} \mathrm{O}_{3}\right)^{+}: 498.1817$, found: 498.1822 .

Compound 4b: 3-methyl-6-phenyl-4-((3"'-(p-tolyl)isoxazol-5"-yl)methyl)-10H-naphtho pyrano[2,3- $d$ ]pyrimidin-11(12H)-one

White solid, yield $93 \%$, mp $138-140{ }^{\circ} \mathrm{C} .{ }^{1} \mathrm{H}$ NMR $\left(300 \mathrm{MHz} ; \mathrm{CDCl}_{3}\right): \delta(\mathrm{ppm})=2.36$ (s, 3H, $\left.\mathrm{H}_{9^{\prime}}\right) ; 2.73\left(\mathrm{~s}, 3 \mathrm{H}, \mathrm{H}_{7^{\prime \prime}}\right) ; 5.11\left(\mathrm{~d}, 1 \mathrm{H}, \mathrm{H}_{4^{\prime \prime}}, J=15.9 \mathrm{~Hz}\right) ; 5.61\left(\mathrm{~d}, 1 \mathrm{H}, \mathrm{H}_{4^{\prime \prime}}, J=15.6 \mathrm{~Hz}\right)$; $5.92\left(\mathrm{~s}, 1 \mathrm{H}, \mathrm{H}_{6}\right) ; 6.54\left(\mathrm{~s}, 1 \mathrm{H}, \mathrm{H}_{2^{\prime \prime}}\right) ; 7.15\left(\mathrm{~d}, 2 \mathrm{H}, \mathrm{H}_{2^{\prime}, 6^{\prime}}, J=7.2 \mathrm{~Hz}\right) ; 7.21-7.28\left(\mathrm{~m}, 5 \mathrm{H}, \mathrm{H}_{\text {arom }}\right)$; $7.35-7.53\left(\mathrm{~m}, 3 \mathrm{H}, \mathrm{H}_{\text {arom }}\right) ; 7.61\left(\mathrm{~d}, 2 \mathrm{H}, \mathrm{H}_{\text {arom }}, J=8.1 \mathrm{~Hz}\right) ; 7.83\left(\mathrm{~m}, 2 \mathrm{H}, \mathrm{H}_{\text {arom }}\right) ; 7.97(\mathrm{~d}, 1 \mathrm{H}$, $\left.\mathrm{H}_{11}, J=7.8 \mathrm{~Hz}\right) .{ }^{13} \mathrm{C}$ NMR $\left(75 \mathrm{MHz} ; \mathrm{CDCl}_{3}\right): \delta(\mathrm{ppm})=21.3,22.9,36.8,39.7,101.7,102.1$, 116.3, 117.4, 123.6, 125.0, 125.5, 126.7, 126.8, 127.1, 128.4, 128.5, 128.5, 129.5, 131.0, 140.4, 143.6, 148.0, 157.9, 159.5, 161.8, 162.8, 166.0. ESI-HRMS [M+H] ${ }^{+}$calcd. For $\left(\mathrm{C}_{33} \mathrm{H}_{25} \mathrm{~N}_{3} \mathrm{O}_{3}\right)^{+}$: 512.1973, found: 512.1988 . 
Compound 4c: 4-(( $3^{\prime \prime}-(p$-methoxyphenyl)isoxazol-5"'-yl)methyl)-3-methyl-6-phenyl$10 H$-naphtho[2,1-b]pyrano[2,3-d]pyrimidin-11(12H)-one

White solid, yield $92 \%$, mp $166-168{ }^{\circ} \mathrm{C} .{ }^{1} \mathrm{H}$ NMR $\left(300 \mathrm{MHz} ; \mathrm{CDCl}_{3}\right): \delta(\mathrm{ppm})=2.71$ $\left(\mathrm{s}, 3 \mathrm{H}, \mathrm{H}_{9^{\prime}}\right) ; 3.84\left(\mathrm{~s}, 3 \mathrm{H}, \mathrm{H}_{7^{\prime \prime}}\right) ; 5.07\left(\mathrm{~d}, 1 \mathrm{H}, \mathrm{H}_{4^{\prime \prime}}, J=15.6 \mathrm{~Hz}\right) ; 5.58\left(\mathrm{~d}, 1 \mathrm{H}, \mathrm{H}_{4^{\prime \prime}}, J=15.9 \mathrm{~Hz}\right) ; 5.91$ $\left(\mathrm{s}, 1 \mathrm{H}, \mathrm{H}_{6}\right) ; 6.50\left(\mathrm{~s}, 1 \mathrm{H}, \mathrm{H}_{2^{\prime \prime}}\right) ; 6.92\left(\mathrm{~d}, 2 \mathrm{H}, \mathrm{H}_{3^{\prime \prime}}, 5^{\prime \prime \prime}, J=9.6 \mathrm{~Hz}\right) ; 6.96\left(\mathrm{~d}, 1 \mathrm{H}, \mathrm{H}_{\text {arom }}, J=7.6 \mathrm{~Hz}\right)$; $7.12\left(\mathrm{~m}, 2 \mathrm{H}, \mathrm{H}_{\text {arom }}\right) ; 7.41-7.48\left(\mathrm{~m}, 5 \mathrm{H}, \mathrm{H}_{\text {arom }}\right) ; 7.64\left(\mathrm{~d}, 2 \mathrm{H}, \mathrm{H}_{2^{\prime \prime \prime}, 6^{\prime \prime \prime}, J},=9.6 \mathrm{~Hz}\right) ; 7.68(\mathrm{~m}, 2 \mathrm{H}$, $\left.\mathrm{H}_{\text {arom }}\right) ; 7.69\left(\mathrm{~d}, 1 \mathrm{H}, \mathrm{H}_{1}, J=7.4 \mathrm{~Hz}\right) .{ }^{13} \mathrm{C} \mathrm{NMR}\left(75 \mathrm{MHz} ; \mathrm{CDCl}_{3}\right): \delta(\mathrm{ppm})=22.4,36.3,39.2$, 54.8, 101.1, 101.5, 113.8, 115.8, 116.9, 120.3, 123.1, 124.5, 126.2, 126.6, 127.7, 127.9, 128.0, 129.0, 130.5, 131.1, 143.1, 147.5, 157.4, 158.9, 160.6, 161.3, 161.9, 165.4. ESI-HRMS [M+H] ${ }^{+}$ calcd. For $\left(\mathrm{C}_{33} \mathrm{H}_{25} \mathrm{~N}_{3} \mathrm{O}_{4}\right)^{+}: 528.1923$, found: 528.1935.

Compound 4d: 4-((3"-(p-chlorophenyl)isoxazol-5"'-yl)methyl)-3-methyl-6-phenyl-10Hnaphtho[2,1-b]pyrano[2,3- $d$ ]pyrimidin-11(12H)-one

White solid, yield $92 \%$, mp 150-152 ${ }^{\circ} \mathrm{C} .{ }^{1} \mathrm{H}$ NMR $\left(300 \mathrm{MHz} ; \mathrm{CDCl}_{3}\right): \delta(\mathrm{ppm})=2.73$ $\left(\mathrm{s}, 3 \mathrm{H}, \mathrm{H}_{9^{\prime}}\right) ; 5.12\left(\mathrm{~d}, 1 \mathrm{H}, \mathrm{H}_{4^{\prime \prime}}, J=15.6 \mathrm{~Hz}\right) ; 5.60\left(\mathrm{~d}, 1 \mathrm{H}, \mathrm{H}_{4^{\prime \prime}}, J=15.9 \mathrm{~Hz}\right) ; 5.91\left(\mathrm{~s}, 1 \mathrm{H}, \mathrm{H}_{6}\right) ; 6.54$ $\left(\mathrm{s}, 1 \mathrm{H}, \mathrm{H}_{2^{\prime \prime}}\right) ; 7.10\left(\mathrm{~m}, 1 \mathrm{H}, \mathrm{H}_{\text {arom }}\right) ; 7.28\left(\mathrm{~m}, 2 \mathrm{H}, \mathrm{H}_{\text {arom }}\right) ; 7.37-7.49\left(\mathrm{~m}, 7 \mathrm{H}, \mathrm{H}_{\text {arom }}\right) ; 7.66(\mathrm{~d}, 2 \mathrm{H}$, $\left.\mathrm{H}_{2^{\prime \prime \prime}, 6^{\prime \prime \prime}}, J=8.7 \mathrm{~Hz}\right) ; 7.67\left(\mathrm{~m}, 2 \mathrm{H}, \mathrm{H}_{\text {arom }}\right) ; 7.96\left(\mathrm{~d}, 1 \mathrm{H}, \mathrm{H}_{11}, J=7.8 \mathrm{~Hz}\right) .{ }^{13} \mathrm{C}$ NMR $(75 \mathrm{MHz}$; $\left.\mathrm{CDCl}_{3}\right): \delta(\mathrm{ppm})=22.9,36.8,39.7,101.7,102.1,116.3,117.4,123.6,125.0,126.7,126.8,127.1$, 128.0, 128.4, 128.5, 128.6, 129.2, 129.5, 131.0, 131.6, 136.3, 143.6, 148.0, 157.8, 159.5, 161.8, 161.9, 166.6. ESI-HRMS $[\mathrm{M}+\mathrm{H}]^{+}$calcd. For $\left(\mathrm{C}_{32} \mathrm{H}_{22} \mathrm{ClN}_{3} \mathrm{O}_{3}\right)^{+}: 532.1427$, found: 532.1437.

Compound 4e: 3-methyl-4-((3"'-phenylisoxazol-5"-yl)methyl)-6-(p-tolyl)-10H-naphtho pyrano[2,3-d]pyrimidin-11(12H)-one

White solid, yield 95\%, mp 157-159 ${ }^{\circ} \mathrm{C} .{ }^{1} \mathrm{H}$ NMR $\left(300 \mathrm{MHz} ; \mathrm{CDCl}_{3}\right): \delta(\mathrm{ppm})=2.19$ (s, 3H, $\left.\mathrm{H}_{9^{\prime}}\right) ; 2.73\left(\mathrm{~s}, 3 \mathrm{H}, \mathrm{H}_{7^{\prime}}\right) ; 5.08\left(\mathrm{~d}, 1 \mathrm{H}, \mathrm{H}_{4^{\prime \prime}}, J=15.6 \mathrm{~Hz}\right) ; 5.63\left(\mathrm{~d}, 1 \mathrm{H}, \mathrm{H}_{4^{\prime \prime}}, J=15.6\right.$ $\mathrm{Hz}) ; 5.88\left(\mathrm{~s}, 1 \mathrm{H}, \mathrm{H}_{6}\right) ; 6.55\left(\mathrm{~s}, 1 \mathrm{H}, \mathrm{H}_{2^{\prime \prime}}\right) ; 7.05\left(\mathrm{~d}, 2 \mathrm{H}, \mathrm{H}_{2^{\prime \prime \prime}, 6^{\prime \prime \prime},} \mathrm{J}=7.8 \mathrm{~Hz}\right) ; 7.14-7.34(\mathrm{~m}, 3 \mathrm{H}$, $\left.\mathrm{H}_{\text {arom }}\right) ; 7.37-7.57\left(\mathrm{~m}, 5 \mathrm{H}, \mathrm{H}_{\text {arom }}\right) ; 7.66\left(\mathrm{~d}, 2 \mathrm{H}, \mathrm{H}_{3^{\prime \prime \prime}}, 5^{\prime \prime \prime}, J=7.8 \mathrm{~Hz}\right) ; 7.83\left(\mathrm{~d}, 2 \mathrm{H}, \mathrm{H}_{5,6}, J=9.0\right.$ $\mathrm{Hz}) ; 7.98\left(\mathrm{~d}, 1 \mathrm{H}, \mathrm{H}_{1}, J=8.1 \mathrm{~Hz}\right) .{ }^{13} \mathrm{C} \mathrm{NMR}\left(75 \mathrm{MHz} ; \mathrm{CDCl}_{3}\right): \delta(\mathrm{ppm})=21.4,22.9,36.3$, $39.7,101.2,101.6,115.9,116.8,123.1,124.5,126.3,126.5,127.5,127.8,128.0,128.6,128.7,128.9$, 130.5, 135.8, 135.9, 140.2, 147.4, 157.2, 158.9, 161.3, 161.4, 166.1. ESI-HRMS [M+H] ${ }^{+}$calcd. For $\left(\mathrm{C}_{33} \mathrm{H}_{25} \mathrm{~N}_{3} \mathrm{O}_{3}\right)^{+}: 512.1974$, found: 512.1981.

Compound 4f: 3-methyl-6-(p-tolyl)-4-(( $3^{\prime \prime}$-( $p$-tolyl)isoxazol-5"-yl)methyl)-10H-naphtho pyrano[2,3-d]pyrimidin-11(12H)-one

White solid, yield $96 \%, \mathrm{mp} 154-156{ }^{\circ} \mathrm{C} .{ }^{1} \mathrm{H}$ NMR $\left(300 \mathrm{MHz} ; \mathrm{CDCl}_{3}\right): \delta(\mathrm{ppm})=1.72$ $\left(\mathrm{s}, 3 \mathrm{H}, \mathrm{H}_{9^{\prime}}\right) ; 2.23\left(\mathrm{~s}, 3 \mathrm{H}, \mathrm{H}_{7^{\prime}}\right) ; 2.72\left(\mathrm{~s}, 3 \mathrm{H}, \mathrm{H}_{7^{\prime \prime}}\right) ; 5.10\left(\mathrm{~d}, 1 \mathrm{H}, \mathrm{H}_{4^{\prime \prime}}, J=15.9 \mathrm{~Hz}\right) ; 5.63(\mathrm{~d}, 1 \mathrm{H}$, $\left.\mathrm{H}_{4^{\prime \prime}}, J=15,9 \mathrm{~Hz}\right) ; 5.89\left(\mathrm{~s}, 1 \mathrm{H}, \mathrm{H}_{6}\right) ; 6.58\left(\mathrm{~s}, 1 \mathrm{H}, \mathrm{H}_{2^{\prime \prime}}\right) ; 7.05\left(\mathrm{~d}, 2 \mathrm{H}, \mathrm{H}_{3^{\prime \prime \prime}, 5^{\prime \prime},}, J=7.8 \mathrm{~Hz}\right) ; 7.26-7.49$ $\left(\mathrm{m}, 6 \mathrm{H}, \mathrm{H}_{\text {arom }}\right) ; 7.61-7.83\left(\mathrm{~m}, 5 \mathrm{H}, \mathrm{H}_{\text {arom }}\right) ; 7.98\left(\mathrm{~d}, 1 \mathrm{H}, \mathrm{H}_{1}, J=8.1 \mathrm{~Hz}\right) .{ }^{13} \mathrm{C} \mathrm{NMR}(75 \mathrm{MHz}$; $\left.\mathrm{CDCl}_{3}\right): \delta(\mathrm{ppm})=20.9,22.9,36.3,39.2,101.8,102.2,116.5,117.4,123.6,125.0,126.7,126.8$, 127.1, 128.3, 128.4, 128.5, 128.8, 128.9, 129.1, 129.4, 130.2, 131.0, 131.6, 136.3, 140.7, 148.0, 157.7, 159.4, 161.8, 162.8, 166.3. ESI-HRMS $[\mathrm{M}+\mathrm{H}]^{+}$calcd. For $\left(\mathrm{C}_{34} \mathrm{H}_{27} \mathrm{~N}_{3} \mathrm{O}_{3}\right)^{+}: 526.2130$, found: 536.2137 .

Compound 4g: 4-((3"-(p-methoxyphenyl)isoxazol-5"-yl)methyl)-3-methyl-6-(p-tolyl)$10 H$-naphtho[2,1-b]pyrano[2,3-d]pyrimidin-11(12H)-one

White solid, yield $94 \%, \mathrm{mp} 144-146{ }^{\circ} \mathrm{C} .{ }^{1} \mathrm{H}$ NMR $\left(300 \mathrm{MHz} ; \mathrm{CDCl}_{3}\right): \delta(\mathrm{ppm})=2.23$ $\left(\mathrm{s}, 3 \mathrm{H}, \mathrm{H}_{9^{\prime}}\right) ; 2.72\left(\mathrm{~s}, 3 \mathrm{H}, \mathrm{H}_{7^{\prime}}\right) ; 3.85\left(\mathrm{~s}, 3 \mathrm{H}, \mathrm{H}_{7^{\prime \prime}}\right) ; 5.06\left(\mathrm{~d}, 1 \mathrm{H}, \mathrm{H}_{4^{\prime \prime}}, J=15.6 \mathrm{~Hz}\right) ; 5.61(\mathrm{~d}, 1 \mathrm{H}$, $\left.\mathrm{H}_{4^{\prime \prime}}, J=15.9 \mathrm{~Hz}\right) ; 5.88\left(\mathrm{~s}, 1 \mathrm{H}, \mathrm{H}_{6}\right) ; 6.52\left(\mathrm{~s}, 1 \mathrm{H}, \mathrm{H}_{2^{\prime \prime}}\right) ; 6.92\left(\mathrm{~d}, 2 \mathrm{H}, \mathrm{H}_{3^{\prime \prime \prime}}, 5^{\prime \prime \prime}, J=8.7 \mathrm{~Hz}\right) ; 6.96$

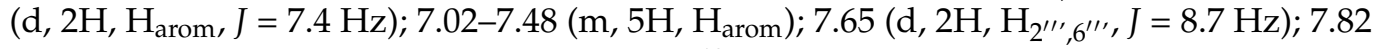
$\left(\mathrm{m}, 2 \mathrm{H}, \mathrm{H}_{\text {arom }}\right) ; 7.98\left(\mathrm{~d}, 1 \mathrm{H}, \mathrm{H}_{11}, J=8.4 \mathrm{~Hz}\right) .{ }^{13} \mathrm{C} \mathrm{NMR}\left(75 \mathrm{MHz} ; \mathrm{CDCl}_{3}\right): \delta(\mathrm{ppm})=20.9$, 22.9, 36.3, 39.7, 55.3, 101.8, 102.0, 114.3, 116.5, 117.4, 120.8, 123.6, 124.9, 127.1,128.2, 128.3, 128.4, 129.1, 129.3, 131.0, 131.5, 136.3, 140.7, 148.0, 157.8, 159.4, 161.1, 161.8, 162.4, 166.0. ESI-HRMS [M+H] $]^{+}$calcd. For $\left(\mathrm{C}_{34} \mathrm{H}_{27} \mathrm{~N}_{3} \mathrm{O}_{4}\right)^{+}: 542.2079$, found: 542.2088 .

Compound $4 \mathrm{~h}$ : 4-((3-(4-chlorophenyl)isoxazol-5-yl)methyl)-3-methyl-6-( $p$-tolyl)-10Hnaphtho[2,1-b]pyrano[2,3- $d$ ]pyrimidin-11(12H)-one

White solid, yield 97\%, mp 140-142 ${ }^{\circ} \mathrm{C} .{ }^{1} \mathrm{H} \mathrm{NMR}\left(300 \mathrm{MHz} ; \mathrm{CDCl}_{3}\right): \delta(\mathrm{ppm})=2.23$ $\left(\mathrm{s}, 3 \mathrm{H}, \mathrm{H}_{9^{\prime}}\right) ; 2.72\left(\mathrm{~s}, 3 \mathrm{H}, \mathrm{H}_{7^{\prime}}\right) ; 5.09\left(\mathrm{~d}, 1 \mathrm{H}, \mathrm{H}_{4^{\prime \prime}}, J=15.9 \mathrm{~Hz}\right) ; 5.62\left(\mathrm{~d}, 1 \mathrm{H}, \mathrm{H}_{4^{\prime \prime}}, J=15.9 \mathrm{~Hz}\right) ; 5.88$ $\left(\mathrm{s}, 1 \mathrm{H}, \mathrm{H}_{6}\right) ; 6.56\left(\mathrm{~s}, 1 \mathrm{H}, \mathrm{H}_{2^{\prime \prime}}\right) ; 7.03\left(\mathrm{~d}, 2 \mathrm{H}, \mathrm{H}_{2^{\prime \prime \prime}, 6^{\prime \prime \prime}, J} J=8.4 \mathrm{~Hz}\right) ; 7.37\left(\mathrm{~m}, 2 \mathrm{H}, \mathrm{H}_{\text {arom }}\right) ; 7.39-7.48$ 
$\left(\mathrm{m}, 5 \mathrm{H}, \mathrm{H}_{\text {arom }}\right) ; 7.65\left(\mathrm{~d}, 2 \mathrm{H}, \mathrm{H}_{3^{\prime \prime \prime}, 5^{\prime \prime}, J}=8.4 \mathrm{~Hz}\right) ; 7.67\left(\mathrm{~m}, 2 \mathrm{H}, \mathrm{H}_{\text {arom }}\right) ; 7.69$ (d, 1H, $\mathrm{H}_{11}$ ， $J=7.8 \mathrm{~Hz}) .{ }^{13} \mathrm{C} \mathrm{NMR}\left(75 \mathrm{MHz} ; \mathrm{CDCl}_{3}\right): \delta(\mathrm{ppm})=21.3,22.9,36.3,39.7,101.8,102.1,116.5$, $117.4,123.6,124.9,125.5,126.6,126.7,127.1,128.3,128.4,129.1,129.3,129.4,129.6,131.0$, $131.5,136.3,140.4,140.7,148.0,157.8,166.1$. ESI-HRMS $[\mathrm{M}+\mathrm{H}]^{+}$calcd. For $\left(\mathrm{C}_{33} \mathrm{H}_{24} \mathrm{ClN}_{3} \mathrm{O}_{3}\right)^{+}$: 546.1584, found: 546.1594 .

Compound 4i: 6-(4-chlorophenyl)-3-methyl-4-((3"'-phenylisoxazol-5"'-yl)methyl)-10Hnaphtho[2,1-b]pyrano[2,3-d]pyrimidin-11(12H)-one

White solid, yield 93\%, mp 122-124 ${ }^{\circ} \mathrm{C} .{ }^{1} \mathrm{H}$ NMR $\left(300 \mathrm{MHz} ; \mathrm{CDCl}_{3}\right): \delta(\mathrm{ppm})=2.71$ $\left(\mathrm{s}, 3 \mathrm{H}, \mathrm{H}_{9^{\prime}}\right) ; 5.09$ (d, 1H, $\left.\mathrm{H}_{4^{\prime \prime}}, J=15.9 \mathrm{~Hz}\right) ; 5.59$ (d, 1H, $\left.\mathrm{H}_{4^{\prime \prime}}, J=15.9 \mathrm{~Hz}\right) ; 5.92\left(\mathrm{~s}, 1 \mathrm{H}, \mathrm{H}_{6}\right)$; $6.57\left(\mathrm{~s}, 1 \mathrm{H}, \mathrm{H}_{2^{\prime \prime}}\right) ; 7.14\left(\mathrm{~d}, 2 \mathrm{H}, \mathrm{H}_{2^{\prime \prime \prime}}, 6^{\prime \prime \prime}, \mathrm{J}=7.5 \mathrm{~Hz}\right) ; 7.14-7.23\left(\mathrm{~m}, 2 \mathrm{H}, \mathrm{H}_{\text {arom }}\right) ; 7.26-7.49$ (m, 9H, $\left.\mathrm{H}_{\text {arom }}\right) ; 7.59-7.72\left(\mathrm{~m}, 2 \mathrm{H}, \mathrm{H}_{\text {arom }}\right) ; 7.49-7.57$ (m, 2H, $\left.\mathrm{H}_{\text {arom }}\right) ; 7.74\left(\mathrm{~d}, 1 \mathrm{H}, \mathrm{H}_{1}, J=7.6 \mathrm{~Hz}\right)$. ${ }^{13} \mathrm{C} \mathrm{NMR}\left(75 \mathrm{MHz} ; \mathrm{CDCl}_{3}\right): \delta(\mathrm{ppm})=22.4,36.3,39.2,101.2,101.7,115.8,116.9,123.1,124.5$, $126.3,127.8,127.9,128.0,128.4,129.0,129.7,130.5,131.1,143.1,147.5,157.4,159.0,161.3$, 162.3, 165.8. ESI-HRMS $[\mathrm{M}+\mathrm{H}]^{+}$calcd. For $\left(\mathrm{C}_{32} \mathrm{H}_{23} \mathrm{ClN}_{3} \mathrm{O}_{3}\right)^{+}: 532.1427$, found: 532.1435.

Compound 4j: 6-(p-chlorophenyl)-3-methyl-4-((3"'-(p-tolyl)isoxazol-5"'-yl)methyl)$10 H$-naphtho[2,1-b]pyrano[2,3-d]pyrimidin-11(12H)-one

White solid, yield 91\%, mp 147-149 ${ }^{\circ} \mathrm{C} .{ }^{1} \mathrm{H}$ NMR $\left(300 \mathrm{MHz} ; \mathrm{CDCl}_{3}\right): \delta(\mathrm{ppm})=2.39$ $\left(\mathrm{s}, 3 \mathrm{H}, \mathrm{H}_{9^{\prime}}\right) ; 2.74\left(\mathrm{~s}, 3 \mathrm{H}, \mathrm{H}_{7^{\prime \prime}}\right) ; 5.15\left(\mathrm{~d}, 1 \mathrm{H}, \mathrm{H}_{4^{\prime \prime}}, J=15.9 \mathrm{~Hz}\right.$ ) $; 5.59\left(\mathrm{~d}, 1 \mathrm{H}, \mathrm{H}_{4^{\prime \prime}}, J=15.6 \mathrm{~Hz}\right)$; $5.89\left(\mathrm{~s}, 1 \mathrm{H}, \mathrm{H}_{6}\right) ; 6.54\left(\mathrm{~s}, 1 \mathrm{H}, \mathrm{H}_{2^{\prime \prime}}\right) ; 7.18-7.28\left(\mathrm{~m}, 4 \mathrm{H}, \mathrm{H}_{\text {arom }}\right) ; 7.36-7.49\left(\mathrm{~m}, 5 \mathrm{H}, \mathrm{H}_{\text {arom }}\right) ; 7.64$ $\left(\mathrm{d}, 2 \mathrm{H}, \mathrm{H}_{\text {arom }}, J=8.1 \mathrm{~Hz}\right) ; 7.89\left(\mathrm{~m}, 3 \mathrm{H}, \mathrm{H}_{\text {arom }}\right) .{ }^{13} \mathrm{C}$ NMR $\left(75 \mathrm{MHz} ; \mathrm{CDCl}_{3}\right): \delta(\mathrm{ppm})=21.4$, 23.0, 36.2, 39,7, 101.5, 102.2, 114.8, 116.5, 117.4, 123.6, 124.9, 125.5, 126.6, 126.7, 127.1, 128.3, $128.4,129.1,129.3,129.4,129.6,131.0,131.5,136.3,140.4,140.7,148.0,157.8,166.1$. ESI-HRMS $[\mathrm{M}+\mathrm{H}]^{+}$calcd. For $\left(\mathrm{C}_{33} \mathrm{H}_{24} \mathrm{ClN}_{3} \mathrm{O}_{3}\right)^{+}: 546.1584$, found: 546.1594 .

Compound 4k: 6-(p-chlorophenyl)-4-((3"-(p-methoxyphenyl)isoxazol-5"'-yl)methyl)3-methyl-10H-naphtho[2,1-b]pyrano[2,3- $d]$ pyrimidin-11(12H)-one

White solid, yield 96\%, mp 160-162 ${ }^{\circ} \mathrm{C} .{ }^{1} \mathrm{H} \mathrm{NMR}\left(300 \mathrm{MHz} ; \mathrm{CDCl}_{3}\right): \delta(\mathrm{ppm})=2.74$ $\left(\mathrm{s}, 3 \mathrm{H}, \mathrm{H}_{9^{\prime}}\right) ; 3.80\left(\mathrm{~s}, 3 \mathrm{H}, \mathrm{H}_{7^{\prime \prime}}\right) ; 5.14\left(\mathrm{~d}, 1 \mathrm{H}, \mathrm{H}_{4^{\prime \prime}}, \mathrm{J}=15.9 \mathrm{~Hz}\right) ; 5.58\left(\mathrm{~d}, 1 \mathrm{H}, \mathrm{H}_{4^{\prime \prime}}, J=16.5 \mathrm{~Hz}\right) ; 5.89$ $\left(\mathrm{s}, 1 \mathrm{H}, \mathrm{H}_{6}\right) ; 6.50\left(\mathrm{~s}, 1 \mathrm{H}, \mathrm{H}_{2^{\prime \prime}}\right) ; 6.97\left(\mathrm{~d}, 2 \mathrm{H}, \mathrm{H}_{3^{\prime \prime \prime}, 5^{\prime \prime \prime}, J}=8.7 \mathrm{~Hz}\right) ; 7.18\left(\mathrm{~d}, 2 \mathrm{H}, \mathrm{H}_{2^{\prime}, 6^{\prime}}, J=8.4 \mathrm{~Hz}\right)$; $7.36\left(\mathrm{~d}, 2 \mathrm{H}, \mathrm{H}_{2^{\prime \prime \prime}, 6^{\prime \prime \prime}, J}=8.7 \mathrm{~Hz}\right) ; 7.26-7.49\left(\mathrm{~m}, 4 \mathrm{H}, \mathrm{H}_{\text {arom }}\right) ; 7.70\left(\mathrm{~d}, 2 \mathrm{H}, \mathrm{H}_{\text {arom }}, J=7.0 \mathrm{~Hz}\right)$; 7.73-7.89 (m, 3H, $\left.\mathrm{H}_{\text {arom }}\right) .{ }^{13} \mathrm{C} \mathrm{NMR}\left(75 \mathrm{MHz} ; \mathrm{CDCl}_{3}\right): \delta(\mathrm{ppm})=22.7,36.2,38.7,55.8$, 101.1, 101.5, 113.8, 115.8, 116.9, 120.3, 123.1, 124.5, 126.2, 126.6, 127.7, 127.9, 128.0, 129.0, $130.5,131.1,143.1,147.5,157.4,158.9,160.6,161.3,161.9,165.4$. ESI-HRMS [M+H] ${ }^{+}$calcd. For $\left(\mathrm{C}_{33} \mathrm{H}_{25} \mathrm{ClN}_{3} \mathrm{O}_{4}\right)^{+}: 562.1533$, found: 562.1548 .

Compound 41: 6-(p-chlorophenyl)-4-((3"-(p-chlorophenyl)isoxazol-5"'-yl)methyl)-3methyl-10H-naphtho[2,1-b]pyrano[2,3-d]pyrimidin-11(12H)-one

White solid, yield 92\%, mp 152-154 ${ }^{\circ} \mathrm{C} .{ }^{1} \mathrm{H} \mathrm{NMR}\left(300 \mathrm{MHz} ; \mathrm{CDCl}_{3}\right): \delta(\mathrm{ppm})=2.74$ $\left(\mathrm{s}, 3 \mathrm{H}, \mathrm{H}_{9^{\prime}}\right) ; 5.16\left(\mathrm{~d}, 1 \mathrm{H}, \mathrm{H}_{4^{\prime \prime}}, J=15.9 \mathrm{~Hz}\right) ; 5.58\left(\mathrm{~d}, 1 \mathrm{H}, \mathrm{H}_{4^{\prime \prime}}, J=15.9 \mathrm{~Hz}\right) ; 5.89\left(\mathrm{~s}, 1 \mathrm{H}, \mathrm{H}_{6}\right)$; $6.53\left(\mathrm{~s}, 1 \mathrm{H}, \mathrm{H}_{2^{\prime \prime}}\right) ; 7.18\left(\mathrm{~m}, 2 \mathrm{H}, \mathrm{H}_{\text {arom }}\right) ; 7.20-7.69\left(\mathrm{~m}, 8 \mathrm{H}, \mathrm{H}_{\text {arom }}\right) ; 7.81-7.83\left(\mathrm{~m}, 2 \mathrm{H}, \mathrm{H}_{\text {arom }}\right)$; 7.85-7.89 (m, 2H, Harom). ${ }^{13} \mathrm{C} \mathrm{NMR}\left(75 \mathrm{MHz} \mathrm{CDCl}_{3}\right): \delta(\mathrm{ppm})=22.9,36.8,39.7,101.2$, $102.1,115.6,117.4,123.4,125.2,126.8,127.3,127.7,127.9,128.0,128.5,128.6,129.0,129.1$, 129.2, 129.3, 129.8, 130.8, 131.6, 132.6, 136.3, 142.0, 148.0, 158.0, 159.5, 161.7, 161.9, 166.5. ESI-HRMS $[\mathrm{M}+\mathrm{H}]^{+}$calcd. For $\left(\mathrm{C}_{33} \mathrm{H}_{21} \mathrm{Cl}_{2} \mathrm{~N}_{3} \mathrm{O}_{3}\right)^{+}: 566.1038$, found: 566.1050 .

The NMR spectra of all synthesized compounds are given as supplementary material.

\subsection{Molecular Docking Procedure}

The chemical compound structures of the co-crystallized inhibitor (N3) and the synthesized compounds (4a-1) were generated and optimized using ACD (3D viewer) software (Version 2017.2.1, http://www.filefacts.com/acd3d-viewer-freeware-info, accessed on 8 July 2021), where their energies were minimized. The structure 6LU7 for RBVS (receptorbased virtual screening) having a catalytic dyad (Cys145 and His41), was selected because of its easy ability to complex with the co-crystallized peptide-like ligand inhibitor N3 used as a reference standard in the present work [28]. The crystal structure of SARS-CoV-2 Mpro (PDB: 6LU7) was obtained from the RSCB data bank (https: / / www.rcsb.org, accessed on 8 July 2021). The protein was prepared by removing the complexed inhibitor ligand and 
water molecules. Then, the polar hydrogens were added followed by appending Kollman charges. Hence, the grid box with dimensions of $40 \times 40 \times 40$ points, spacing of $1.0 \AA$ and centered with coordinates $x:-11.993, y: 15.425$, and z: 65.951 , was generated based on N3 binding position in the target protein binding site. The molecular docking analysis of N3 and the synthesized compounds (4a-1) were performed using AutoDock Vina software (The Scripps Research Institute, La Jolla, CA, USA) [39]. Molecule-enzyme interactions were drawn and construed by employing the Biovia Discovery Studio Visualizer, BIOVIA, San Diego, CA, USA (2017).

\section{Conclusions}

In conclusion, we have successfully synthesized in this work a new series of 3,5isoxazole linked naphthopyranopyrimidinones $\mathbf{4 a - 1}$, in three steps, using the naphtopyranyl moiety as a building blocks support, via 1,3-dipolar cycloaddition reaction using arylnitrile oxides catalyzed by $\mathrm{Cu}(\mathrm{I})$ under classical and microwave irradiation conditions. The last condition offers several advantages including good-to-high yields, cleaner products, and a reduction in reaction time, making this method particularly attractive. In addition, to help fight COVID-19, molecular docking based on virtual screening was performed to identify among the newly synthesized compounds $\mathbf{4 a - 1}$ which ones has the potential to interact with COVID-19 Mpro. Our results demonstrate that compounds $4 a$, $4 \mathbf{e}$, $\mathbf{4 h}, \mathbf{4 i}, \mathbf{4} \mathbf{j}$ and $\mathbf{4 k}$, exhibited good binding affinity towards the main protease of COVID-19 $\left(\mathrm{M}^{\text {pro }}\right)$ better than that made by the native co-ligand N3 inhibitor. These molecules could possibly be promising in terms of therapeutic effect against SARs-CoV-2. However, in vitro and then in vivo investigation are essential to validate our prediction results and pave the way for the discovery of anti-SARs-CoV-2 drugs.

Supplementary Materials: The following are available online, NMR spectra of the synthesized compounds $4 a-1$.

Author Contributions: Conceptualization, F.K.A., M.C. and S.J.; methodology, A.R. and N.B.H.; formal analysis, M.R.E., M.A.A. and S.J.; investigation, F.K.A., M.C. and S.J.; resources, F.K.A., H.B.J. and A.R.; data curation, H.B.J. and S.J.; writing - original draft preparation, F.K.A., M.C. and S.J.; writing-review and editing, F.K.A. and H.B.J.; supervision, N.B.H. and H.B.J.; funding acquisition, F.K.A. All authors have read and agreed to the published version of the manuscript.

Funding: This research received on external funding.

Institutional Review Board Statement: Not applicable.

Informed Consent Statement: Not applicable.

Data Availability Statement: Not applicable.

Acknowledgments: This research was supported by the Deanship of Scientific Research, Imam Mohammad IbnSaud Islamic University (IMSIU), Saudi Arabia, Grant No. (21-13-18-063).

Conflicts of Interest: The authors declare no conflict of interests.

Sample Availability: Samples of the compounds $4 a-1$ are available from the authors.

\section{References}

1. Cascella, M.; Rajnik, M.; Cuomo, A.; Dulebohn, S.C.; Di Napoli, R. Features, Evaluation and Treatment Coronavirus (COVID-19); Stat Pearls Publishing: Treasure Island, FL, USA, 2020.

2. Sohrabi, C.; Alsafi, Z.; O’Neill, N.; Khan, M.; Kerwan, A.; Al-Jabir, A.; Iosifidis, C.; Agha, R. World Health Organization declares global emergency: A review of the 2019 novel coronavirus (COVID-19). Int. J. Surg. 2020, 76, 71-76. [CrossRef]

3. Li, H.; Zhou, Y.; Zhang, M.; Wang, H.; Zhao, Q.; Liu, J. Updated Approaches against SARS-CoV. Antimicrob. Agents Chemother. 2020, 64, e00483-20. [CrossRef]

4. Shen, A.Y.; Hwang, M.H.; Roffler, S.; Chen, C.F. Cytotoxicity and antimicrobial activity of some naphthol derivatives. Arch. Pharm. 1995, 328, 197-201. [CrossRef] [PubMed]

5. Shen, A.Y.; Tsai, C.T.; Chen, C.L. Synthesis and cardiovascular evaluation of N-substituted aminonaphthols. Eur. J. Med. Chem. 1999, 34, 877-882. [CrossRef] 
6. Huang, M.H.; Wu, S.N.; Wang, J.P.; Lin, C.H.; Lu, S.I.; Liao, L.F.; Shen, A.Y. Biological Study of Naphthalene Derivatives with Antiinflammatory Activities. Drug Dev. Res. 2003, 60, 261-269. [CrossRef]

7. Ratia, K.; Pegan, S.; Takayama, J.; Sleeman, K.; Coughlin, M.; Baliji, S.; Chaudhuri, R.; Fu, W.; Prabhakar, B.S.; Johnson, M.E.; et al. A noncovalent class of papain-like protease/deubiquitinase inhibitors blocks SARS virus replication. Proc. Natl. Acad. Sci. USA 2008, 105, 16119-16124. [CrossRef]

8. Ghosh, A.K.; Takayama, J.; Rao, K.V.; Ratia, K.; Chaudhuri, R.; Mulhearn, D.C.; Lee, H.; Nichols, D.B.; Baliji, S.; Baker, S.C.; et al. Severe Acute Respiratory Syndrome Coronavirus Papain-like Novel Protease Inhibitors: Design, Synthesis, Protein-Ligand X-ray Structure and Biological Evaluation. J. Med. Chem. 2010, 53, 4968-4979. [CrossRef]

9. Eid, F.A.; Abd El-Wahab, A.H.F.; El-Hagali, G.A.M.; Khafagy, M.M. Syhthesis and antimicrobial evaluation of naphtho[2,1$b$ ]pyrano[2,3-d]pyrimidine and pyrano[3,2-e][1,2,4] triazolo[1,5-c]pyrimidine derivatives. Acta Pharm. 2004, 54, 13-26.

10. Eiden, F.; Denk, F. Synthesis and CNS-activity of pyrane derivatives 6,8-dioxabicyclo(3,2,1)octanes. Arch. Pharm. 1991, 324, 353-354. [CrossRef]

11. Taylor, N.R.; Cleasby, A.; Singh, O.; Skarzynski, T.; Wonacott, A.J.; Smith, P.W.; Sollis, S.L.; Howes, P.D.; Cherry, P.C.; Bethell, R.; et al. Dihydropyrancarboxamides related to zanamivir: A new series of inhibitors of influenza virus sialidases. Crystallographic and molecular modeling study of complexes of 4-amino-4H-pyran-6-carboxamides and sialidase from influenza virus types A and B. J. Med. Chem. 1998, 41, 798-807. [CrossRef]

12. Li, C.J.; Zhang, L.J.; Dezube, B.J.; Crumpacker, C.S.; Pardee, A.B. Three inhibitors of type 1 human immunodeficiency virus long terminal repeat-directed gene expression and virus replication. Proc. Natl. Acad. Sci. USA 1993, 90, 1839-1842. [CrossRef]

13. Rajendran, A.; Raghupathy, D.; Priyadarshini, M. Green synthesis of biologically active pyrazolopyrimidine derivatives using an ionic liquid 2-methyl-3-butyl imidazolium chloride. Int. J. Chem. Tech. Res. 2011, 3, 293-397.

14. Modia, P.; Patela, S.; Chhabria, M. Structure-based design, synthesis and biological evaluation of a newer series of pyrazolo[1,5a]pyrimidine analogues as potential anti-tubercular agents. Bioorg. Chem. 2019, 87, 240-251. [CrossRef] [PubMed]

15. Hu, H.; Dong, Y.; Li, M.; Wang, R.; Zhang, X.; Gong, P.; Zhao, Y. Design, synthesis and biological evaluation of novel thieno[3,2- $d]$ pyrimidine and quinazoline derivatives as potent antitumor agents. Bioorg. Chem. 2019, 90, 103086. [CrossRef] [PubMed]

16. Mirmortazavi, S.S.; Farvandi, M.; Ghafouri, H.; Mohammadi, A.; Shourian, M. Evaluation of novel pyrimidine derivatives as a new class of mushroom tyrosinase inhibitor. Drug Des. Devel. Ther. 2019, 13, 2169-2178. [CrossRef]

17. Yanga, F.; Yub, L.Z.; Diaoa, P.C.; Jiana, X.E.; Zhoua, M.F.; Jianga, C.S.; Youa, W.W.; Mab, W.F.; Zhao, P.L. Novel [1,2,4]triazolo[1,5a]pyrimidine derivatives as potent antitubulin agents: Design, multicomponent synthesis and antiproliferative activities. Bioorg. Chem. 2019, 92, 103260. [CrossRef]

18. Somakala, K.; Tariq, S.; Amir, M. Synthesis, evaluation and docking of novel pyrazolo pyrimidines as potent p38 $\alpha$ MAP kinase inhibitors with improved anti-inflammatory, ulcerogenic and TNF- $\alpha$ inhibitory properties. Bioorg. Chem. 2019, 87, 550-559. [CrossRef] [PubMed]

19. Acosta, R.S.; Jung, E.; Qiu, L.; Wilson, D.J.; Geraghty, R.J.; Chen, L. 4,7-Disubstituted 7H-Pyrrolo[2,3- $d$ ]pyrimidines and Their Analogs as Antiviral Agents against Zika Virus. Molecules 2021, 26, 3779. [CrossRef]

20. Hockova, D.; Holy, A.; Masojidkov, M.; Andrei, G.; Snoeck, R.; De Clercqb, E.; Balzarini, J. Synthesis and antiviral activity of 2,4-diamino-5-cyano-6-[2-(phosphonomethoxy)ethoxy]pyrimidine and related compounds. Bioorg. Med. Chem. 2004, 12, 3197-3202. [CrossRef]

21. Abdelall, E.K.A. Synthesis and biological evaluations of novel isoxazoles and furoxan derivative as anti-inflammatory agents. Bioorg. Chem. 2020, 94, 103441. [CrossRef]

22. Das Neves, A.R.; Trefzger, O.S.; Barbosa, N.V.; Honorato, A.M.; Carvalho, D.B.; Moslaves, I.S.; Kadri, M.C.T.; Yoshida, N.C.; Kato, M.J.; Arruda, C.C.P.; et al. Effect of isoxazole derivatives of tetrahydrofuran neolignans on intracellular amastigotes of Leishmania (Leishmania) amazonensis: A structure-activity relationship comparative study with triazole-neolignan-based compounds. Chem. Biol. Drug Des. 2019, 94, 2004-2012. [CrossRef]

23. De Souza, A.N.A.; Xavier, V.F.; Coelho, G.S.; Junior, P.A.S.; Romanha, A.J.; Murta, S.M.F.; Carneiroc, C.M.; Taylor, J.G. Synthesis of 3,5-Diarylisoxazole Derivatives and Evaluation of in vitro Trypanocidal Activity. J. Braz. Chem. Soc. 2018, 29, 269-277. [CrossRef]

24. Reddy, S.P.; Yamini, G.; Sowmya, D.V.; Padmavathi, V.; Padmaja, A. Synthesis and Antimicrobial Activity of Some New 3,5-Disubstituted Pyrazoles and Isoxazoles. Med. Chem. 2017, 7, 371-380. [CrossRef]

25. Thotla, K.; Noole, V.G.; Kedika, B.; Reddy, K. An Efficient Synthesis and Antimicrobial Activity of 5-\{2-[(1-Aryl-1H-1,2,3-triazol-4yl)methoxy]- 5-bromophenyl\}isoxazoles. Russ. J. Gen. Chem. 2019, 89, 789-793. [CrossRef]

26. Yang, Z.B.; Li, P.; He, Y.J. Design, Synthesis, and Bioactivity Evaluation of Novel Isoxazole-Amide Derivatives Containing an Acylhydrazone Moiety as New Active Antiviral Agents. Molecules 2019, 24, 3766. [CrossRef] [PubMed]

27. Lee, Y.S.; Park, S.M.; Kim, B.H. Synthesis of 5-isoxazol-5-yl-20-deoxyuridines exhibiting antiviral activity against HSV and several RNA viruses. Bioorg. Med. Chem. Lett. 2009, 19, 1126-1128. [CrossRef] [PubMed]

28. Jin, Z.; Du, X.; Xu, Y.; Deng, Y.; Liu, M.; Zhao, Y.; Zhang, B.; Li, X.; Zhang, L.; Peng, C.; et al. Structure of Mpro from SARS-CoV-2 and discovery of its inhibitors. Nature 2020, 582, 289-293. [CrossRef] [PubMed]

29. Abu-Zaied, M.A.; Elgemeie, G.H.; Mahmoud, N.M. Anti-Covid-19 Drug Analogues: Synthesis of Novel Pyrimidine Thioglycosides as Antiviral Agents Against SARS-COV 2 and Avian Influenza H5N1 Viruses. ACS Omega 2021, 6, 16890-16904. [CrossRef] 
30. Soltane, R.; Chrouda, A.; Mostafa, A.; Al-Karmalawy, A.A.; Chouaïb, K.; Dhahri, A.; Pashameah, R.A.; Alasiri, A.; Kutkat, O.; Shehata, M.; et al. Strong Inhibitory Activity and Action Modes of Synthetic Maslinic Acid Derivative on Highly Pathogenic Coronaviruses: COVID-19 Drug Candidate. Pathogens 2021, 10, 623. [CrossRef]

31. Ben Said, A.; Rahmouni, A.; Daami-Ramadi, M.; Romdhane, A.; Ben Jannet, H. Design and Synthesis of new antimicrobial $[1,2,4]$ triazolo[1,5-c]pyrimidines. J. Tun. Chem. Soc. 2017, 19, 94-104.

32. Cherif, M.; Debbabi, M.; Chortani, S.; Romdhane, A.; Ben Jannet, H. Design and synthesis of new naphtho[2,1-b]pyrano [2,3-d]pyrimidinones under classical and microwave conditions. Turk. J. Chem. 2018, 42, 1623-1639. [CrossRef]

33. Debbabi, M.; Nimbarte, V.D.; Chekir, S.; Chortani, S.; Romdhane, A.; Ben jannet, H. Design and synthesis of novel potent anticoagulant and anti-tyrosinase pyranopyrimidines and pyranotriazolopyrimidines: Insights from molecular docking and SAR analysis. Bioorg. Chem. 2019, 82, 129-138. [CrossRef]

34. Zayane, M.; Romdhane, A.; Remadi, M.D.; Ben Jannet, H. Access to new antimicrobial 4-methylumbelliferone derivatives. J. Chem. Sci. 2015, 127, 1619-1626. [CrossRef]

35. Romdhane, A.; Martin, M.T.; Ben Said, A.; Jabrane, A.; Ben Jannet, H. Synthesis of new acetylcholinesterase inhibitors Naphto[2,1B]pyrano[3,2-E][1,2,4]triazolo[1,5-C]pyrimidine derivatives. J. Tun. Chem. Soc. 2012, 14, 127-135.

36. Mohammed, F.K.; Soliman, A.Y.; Sawy, A.S.; Badre, M.G. 2-Amino-5- hydroxy-4-phenyl-7-methyl-4H[1-chromeno-3-carbonitrile] as a key precursor for the synthesis of several chromene based heterocyclic systems. J. Chem. Pharm. Res. 2009, 1, $213-224$.

37. Hesek, D.; Lee, M.; Noll, B.C.; Fisher, J.F.; Mobashery, S. Complications from Dual Roles of Sodium Hydride as a Base and as a Reducing Agent. J. Org. Chem. 2009, 74, 2567-2570. [CrossRef] [PubMed]

38. Chouaib, K.; Romdhane, A.; Delemasure, S.; Dutartre, P.; Elie, N.; Touboul, D.; Ben Jannet, H.; Hamza, M.A. Regiospecific synthesis, anti-inflammatory and anticancer evaluation of novel 3,5-disubstituted isoxazoles from the natural maslinic and oleanolic acids. Ind. Crop. Prod. 2016, 85, 287-299. [CrossRef]

39. Trott, O.; Olson, A.J. Software News and Update AutoDock Vina: Improving the Speed and Accuracy of Docking with a New Scoring Function, Efficient Optimization, and Multithreading. J. Comput. Chem. 2010, 31, 455-461. [CrossRef] 